Research Report No. 30/2008

\title{
Assessing the Long-Run Economic Impact of Labour Law Systems: A Theoretical Reappraisal and Analysis of New Time Series Data
}

Simon Deakin

Prabirjit Sarkar

Follow this and additional works at: http:/ / digitalcommons.osgoode.yorku.ca/clpe

\section{Recommended Citation}

Deakin, Simon and Sarkar, Prabirjit, "Assessing the Long-Run Economic Impact of Labour Law Systems: A Theoretical Reappraisal and Analysis of New Time Series Data" (2008). Comparative Research in Law \& Political Economy. Research Paper No. 30/2008.

http://digitalcommons.osgoode.yorku.ca/clpe/201 


\section{Simon Deakin and Prabirjit Sarkar}

Assessing the Long-Run Economic Impact of Labour Law Systems: A Theoretical Reappraisal and Analysis of New Time Series Data

EDITORS: Peer Zumbansen (Osgoode Hall Law School, Toronto, Director, Comparative Research in Law and Political Economy, York University), J ohn W. Cioffi (University of California at Riverside), Lindsay Krauss (Osgoode Hall Law School, Toronto, Production Editor) 

CLPE Research Paper 30/2008

Vol. 04 No. 06 (2008)

\title{
Simon Deakin and Prabirjit Sarkar
}

\section{ASSESSING THE LONG-RUN ECONOMIC IMPACT OF LABOUR LAW SYSTEMS: A THEORETICAL REAPPRAISAL AND ANALYSIS OF NEW TIME SERIES DATA}

\begin{abstract}
Standard economic theory sees labour law as an exogenous interference with market relations and predicts mostly negative impacts on employment and productivity. We argue for a more nuanced theoretical position: labour law is, at least in part, endogenous, with both the production and the application of labour law norms influenced by national and sectoral contexts, and by complementarities between the institutions of the labour market and those of corporate governance and financial markets. Legal origin may also operate as a force shaping the content of the law and its economic impact. Time-series analysis using a new dataset on legal change from the 1970s to the mid-2000s shows evidence of positive correlations between regulation and growth in employment and productivity, at least for France and Germany. No relationship, either positive or negative is found for the UK and although the US shows a weak negative relationship between regulation and employment growth, this is offset by productivity gains.
\end{abstract}

Keywords: labour law, employment, productivity, redistribution, complementarities, legal origins, varieties of capitalism

JEL classification: K31, J83 


\section{Author Contacts:}

Simon Deakin

Professor of Law

University of Cambridge

Email: s.deakin@cbr.cam.ac.uk

Prabirjit Sarkar

Professor of Economics

Jadavpur University, Kolkata

Email: prabirjit@gmail.com 



\title{
ASSESSING THE LONG-RUN ECONOMIC IMPACT OF LABOUR LAW SYSTEMS: A THEORETICAL REAPPRAISAl AND ANALYSIS OF NeW TIME SERIES DATA
}

\author{
Simon Deakin and Prabirjit Sarkar ${ }^{*}$
}

\section{INTRODUCTION}

The issue of the economic impact of labour laws has been the focus of intense inquiry and debate at transnational level since the early 1990s, with the publication of the OECD's Jobs Study (OECD, 1994), and before that played a significant role in the formation of public policy in certain countries, most notably America and Britain, which underwent a process of labour market deregulation in the course of the 1980s. Throughout this period the predominant view within economic theory has been to see labour law rules as interferences with the operation of markets, and as therefore requiring justification on market-failure or related grounds if they are not to result in inefficiencies or distortions. Yet it has proved surprisingly difficult to demonstrate empirically that labour law rules have the negative effects contended for them (see Baker et al., 2005). One possible reason for this is that labour law rules have many beneficial economic impacts which may operate alongside, or offset the effects of, their negative ones: these include overcoming the wage- and employment-

\footnotetext{
* Simon Deakin (s.deakin@cbr.cam.ac.uk) is Professor of Law in the Faculty of Law and director of the corporate governance programme at the Centre for Business Research, University of Cambridge. Prabirjit Sarkar (prabirjit@gmail.com) is Professor of Economics at Jadavpur University, Kolkata, and Visiting Fellow at the Centre for Business Research, University of Cambridge. We are grateful to Mathias Siems and to an anonymous referee for comments on an earlier draft. We also gratefully acknowledge financial support from the ESRC's World Economy and Finance Programme, the Isaac Newton Trust, and the EU's Sixth Research and Development Framework Programme (Integrated Project 'Reflexive Governance in the Public Interest').
} 
depressing effects of employer monopsony (Card and Krueger, 1997; Manning, 2005), encouraging firms to use labour more productively (Rubery and Edwards, 2003), stabilizing employment over the economic cycle (Amable, Demmou and Gatti, 2007), and promoting a cooperative industrial relations climate with knock-on effects in terms of the reduction of unemployment (Feldmann, 2008). Labour law is also highly effective in promoting social goals such as the reduction of wage inequality (Freeman, 2005).

Alongside this empirical reassessment, there has been a growing interest in theories which view labour law, together with other forms of market regulation, in comparative political economy terms. In this approach, labour laws are seen as the outcome of macroeconomic conditions, interest-group configurations and legal-political structures which are embedded in particular national contexts. Labour laws are therefore, in part at least, endogenous to the wider economic and political systems within they operate. An implication of this approach is that legal rules do not operate in a straightforwardly instrumental way to reshape economic outcomes. This is for several reasons. Formal legal rules are not so much external forces reshaping markets according to political will, as they are codified conventions which to a certain extent reflect and embody existing market practices. The impacts of changes in the formal law are mediated through self-regulatory mechanisms and social norms of varying degrees of formality, introducing an element of unpredictability into their operation. In addition, legal rules do not operate upon exchange relationships in isolation, but in conjunction with other, interlocking elements within the regulatory framework. In particular, labour regulations interact with complementary mechanisms such as corporate governance rules and product market regulation (Amable, 2004). For these various reasons, then, changes to labour law institutions may not have the effects predicted for them by orthodox supply-and-demand models.

A related feature of recent analyses has been the attempt to achieve a better empirical understanding of legal systems. The legal origins school has focused attention on the role which legal infrastructure - broadly speaking, the institutional framework for rule-making in a given society plays in shaping the substantive content of regulation (La Porta et al., 2008). To study this effect, novel empirical methods, involving the 
construction of indices attempting to measure the intensity of legal regulation across national regimes, have been developed. The strong-form legal origins hypothesis, which claims to identify a sharp bifurcation of legal systems along the lines of the common law/civil law divide, remains highly contentious both theoretically and empirically (see Ahlering and Deakin, 2007). However, the idea that legal institutions may be responsible, in part at least, for the persistence of cross-national diversity in approaches to economic regulation, is in the process of gaining wider acceptance, and thereby opening up new lines of analysis.

In this paper we seek to advance the debate over the economic impact of labour law in two ways. We aim firstly to show how re-theorising law as an embedded institutional phenomenon, at least partly endogenous to the process of economic development within market economies, results in new perspectives on the economic impact of labour law rules. Section 2 reviews the relevant theories. Then we address the empirical question of how changes to labour law impact on the economy by introducing new evidence in the form of time-series data on legal change. To this end, section 3 discusses the methodology of index construction as it applies to labour law and other forms of legal regulation of the business enterprise (company and insolvency law), and presents first results from a newly created dataset examining changes in labour law in three major European countries, as well as the US, since the early 1970s. Section 4 concludes.

\section{THEORETICAL PERSPECTIVES ON THE ECONOMIC EFFECTS OF LABOUR LAW RULES}

\section{A. ECONOMIC AND POLITICAL FORCES SHAPING LABOUR MARKET INSTITUTIONS}

The standard economic critique of labour regulation takes the view that labour law rules operate as external interferences with market relations. This is to assume not simply that the market operates, in the absence of legal regulation, in a self-equilibrating way, correcting itself in response to temporary distortions or imperfections; it is also to assume that legal institutions are exogenous to the processes of market formation and

operation. Labour law rules, it is suggested, originate largely in the rent- 
seeking activities of organized interest groups. Rent-seeking reduces efficiency by channeling resources away from wealth-creation to redistribution. More generally, while labour law rules may be seen as responses to market failures which include monopsony effects and asymmetries of information, regulatory failure is also a strong possibility, with the result that labour laws are rarely matched in a precise way to the inefficiencies they purport to address; they are just as likely to introduce fresh distortions.

This view has been challenged by a variety of approaches in which labour market institutions, including labour laws and regulations, are seen as endogenously generated by a combination of economic and political forces operating at the level of nation states (and, to a lesser degree, at subnational regional level and at transnational level). The starting point is to understand institutions as devices for coordinating the expectations of actors. As responses to market failures of various kinds, they emerge out of particular market settings. Norms of varying degrees of formality embody or encode solutions to coordination problems which have stood the test of time. They are not distributionally neutral; they involve compromises on rent-sharing which, if they endure, can provide the basis for long-term contractual cooperation. The basic form of the employment contract in developed market economies is an illustration of this: the contract reserves powers of coordination and control to the employer in return for access to mechanisms of insurance and income smoothing which protect the worker against risks inherent in employee status, including unemployment. The 'contract' in this sense refers both to a convention which is widely, if sometimes loosely, understood by market actors, and also to a formal legal institution which is 'script-coded' within the discourse of the legal system (Carvalho and Deakin, 2008). The legal system associates 'employment' with a certain normative structure, which is derived, in part, from practices which have grown up around contracting in labour markets, and in part reflects the internal conceptual or dogmatic language used by the law to describe those relationships. The law does not simply impose normative expectations of behaviour from outside; it also, to some degree, crystallizes social practices which are drawn from the experiences of market actors (Deakin, 2003).

The core institutions of labour law - including collective bargaining laws, unemployment insurance schemes, minimum wage laws, and employment 
protection legislation - are based to a large degree on models first developed at the level of particular industries or firms, or in certain localities. State-based unemployment compensation systems at the turn of the twentieth century drew on the practice of northern European cities and localities (one particularly influential model was known as the 'Ghent system') and on trade unions' schemes for mutual insurance. The statutory model of codetermination in Germany has multiple origins which include the paternalistic practices of large firms as well as workers' attempts at self-organisation in the early decades of the twentieth century. The mid-twentieth century arrival of unfair dismissal legislation took place against the widespread use of structured internal labour markets and bureaucratic management techniques in large firms. In the European context, each of these legislative initiatives has been supported, at one point or another, by both management and labour (although not always by both at the same time), and in some cases they were introduced by centreright parties. Labour legislation cannot be explained as serving the interests of organized labour alone.

The legal system, as it is able to mobilise the monopoly of enforcement which an effective state possesses, extends and standardizes practices which are perceived to have been successful at firm or industry level. The standardisation of social practices through law is a technique used to reduce the transaction costs which would otherwise be involved in market actors searching for solutions from scratch each time a coordination failure arose (Warneryd, 1998). It also helps to reduce the threat of mutual defection in prisoner's-dilemma type situations, where individually rational behaviour would lead to a net welfare loss (Hyde, 2006). However, no legal rule operates on the basis of perfect enforcement. Legal sanctions can alter incentives, but the successful implementation of legal rules necessarily depends to some degree on the existence of the understandings of market actors, beyond the legal system itself (Aoki, 2001). Bargaining takes place not on the assumption of the complete legal enforcement of contracts, but 'in the shadow of legal rules' which may be triggered in an endgame situation, but which most of the time remain in the background.

Labour laws, like any other form of market regulation, are not made in a vacuum, and nor are they the result of a purely disinterested and technocratic process of rule formation, although there is a role for 
expertise in their drafting. Because they have (and are meant to have) redistributive consequences, they reflect the power and influence of interest groups and their capacity to mobilize the political process to their ends. Solutions which 'work' for some groups will normally involve losses for others, and will be resisted even if they give rise to net welfare gains at a societal level. However, the process of rule formation is not just an expression of the relative bargaining positions of the different interest groups. Because legal and political institutions are relatively slow to change in relation to the macroeconomic and political cycles, they may have an independent role in framing the interactions of the groups; in particular, they may alter their composition and shape the coalitions they make. More generally, the relative rigidity and longevity of institutions implies a role for complementarities of various kinds which then generate cross-national diversity of practice.

An example of this, which has been extensively studied in the comparative political economy literature, is the influence of voting systems. A link has been suggested between proportional representation and interest group support for a mix of policies involving a high level of employment protection, on the one hand, and legal support for the concentration of share ownership, on the other. This is said to be because proportional representation encourages coalition building between interest groups representing labour market insiders and corporate blockholders. It is argued that in majority-voting systems, by contrast, the most likely interest-group alignments are those which favour a conjunction of financial market liberalization and labour market flexibility (Gourevitch and Shinn, 2005; Pagano and Volpin, 2005).

Macroeconomic conditions may play a role in shaping institutions. For example, high and persistent unemployment may be a factor in rising union density, in systems, such as the Nordic ones, where unions rather than the state play the main role in providing social insurance (Checchi and Nunziata, 2007); in systems where unions' main function is wage determination, such as Britain, union membership and militancy fluctuate according to the strength or weakness of inflationary pressures. Because union strength has been one of the factors affecting the content of labour law in Britain, at least during most of the twentieth century, there is a relationship between the inflationary cycle and the trajectory of labour legislation (Deakin and Wilkinson, 2005: ch. 4). If union membership and 
activity on the one hand and labour legislation on the other are endogenous to the macroeconomic cycle, it becomes difficult to disentangle the direction of causation: do institutional changes have economic impacts or are they themselves the consequence of macroeconomic shifts (Rodrik, 2005)?

Some accounts see present-day institutional configurations as having deep historical roots. Iversen and Soskice (2007) argue that the divergence between liberal market and coordinated market systems can be traced back to the period, in the late nineteenth and early twentieth centuries, when the modern institutions of representative democracy were being formed in western Europe. Systems which opted for proportional representation (PR) ended up favouring coalition building and consensus-based policies, which resulted in a bias towards redistribution, wage compression, economic coordination and strong welfare states. By contrast, majoritarian voting systems had a centre-right bias, which over time resulted in a tendency towards limited redistribution, minimal welfare states, and a liberal economic framework. In coordinated market systems, employers accepted unemployment compensation systems based on high replacement rates and, in time, the complementary institution of employment protection legislation, in order to encourage workers to invest in firm-specific skills. In liberal market systems, which placed les emphasis on firm-specific skill formation, neither employers nor workers had strong incentives to press for strict employment protection or high replacement rates in unemployment insurance. Why then did certain systems adopt PR at the critical point of institutional development at the end of the nineteenth century? Iversen and Soskice's detailed argument on this point is that in the Nordic and northern European systems, industrialization took place in a context where economic coordination through guild systems and localized forms of employer and worker solidarity remained strong, and where a proto-corporatist framework of political representation of organized economic groupings or, as they were traditionally known, 'estates', continued to operate. In Britain, by contrast, guild systems were largely swept away in the early nineteenth century, and associational interests did not have direct representation in the political process. The upshot is that 'the advanced countries with strong welfare states today are those in which economies were locally coordinated a century and a half ago; and whose state tradition was one of 
functional representation and limited autonomy of government to different interests' (Iversen and Soskice, 2007: 37).

\section{B. THE LEGAL SYSTEM AS A SOURCE OF PATH-DEPENDENCE AND CROSS-NATIONAL DIVERSITY: THE LEGAL ORIGIN HYPOTHESIS}

Legal origins theory offers another long-run historical explanation for diversity, but sees the legal system itself, and more precisely legal infrastructure or the framework for law-making, as a principal cause of the persistence of national patterns of regulation and for divergence at a crossnational level. Common law systems, because of the predominant role they are thought to accord to judge-made law over that of legislation as a form of rule-making, are said to have a bias in favour of market-creating rules and a laissez-faire approach to the governance of the business enterprise. In civil law systems, reliance on codes and general statutory restatements of legal principle is seen as privileging a regulatory style which results in redistribution at the expense of wealth creation, and is predisposed towards market regulation (Glaeser and Shleifer, 2002). Two 'channels' are identified as the links between legal infrastructure and the substantive content of rules: an 'adaptability' channel, according to which the common law is inherently more adaptive than the civil law in the sense of being responsive to a changing economic environment, as a consequence of the priority accorded to judicial rule making (Beck, Demirgüc-Kunt and Levine, 2003), and a 'political' channel, according to which the civil law, because of its regulatory bias, offers greater opportunities for (inefficient) rent-seeking (Rajan and Zingales, 2003).

Legal origin theory sees a major role for the transplantation of legal norms as a source of path dependence in institutions. Laws can be transplanted from outside the national system concerned, by virtue of the borrowing or copying of legislative models, compliance with international standards, or through the imposition of laws following conquest or colonialisation. The legal origin approach sees transplantation as an external influence on legal development, on the basis that nearly all systems in the world have drawn the their basic legal infrastructure from one of the original common law or civil law models. These parent systems aside, the legal system can 
therefore be understood as having an exogenous impact on long-run institutional development and economic growth.

One objection to the legal origin approach is that it takes an overly mechanical view of the process of legal transplantation. It ignores the high degree of borrowing that has gone on between systems, even before the adoption of the principal private law codes in the civil law at the start of the nineteenth century; all national systems are, to some degree, hybrids which contain elements of the regulatory styles associated with the common law and civil law families (Siems, 2007). It also overlooks numerous example of the 'endogenisation' of legal rules which occurs as part of the borrowing process; legal models which originate in a given system can be adapted to local conditions. The adaptation process is never complete but nor is complete rejection the norm; it may be most accurate to speak not of 'transplants' but of 'irritants' or catalysts which may well trigger unexpected effects in the host systems, but which are rarely without consequences of some kind (Teubner, 2001).

A further difficulty with the legal origins approach is the somewhat oversimplified account it gives of the common law/civil law divide (see Ahlering and Deakin, 2007). While it is the case that civilian systems do not formally recognize case law as a source of law in the same sense as the provisions of the private law codes, there is a long record of judicial innovation, not least in those areas of the law which touch directly on the business enterprise (company and labour law), in civil law systems; conversely, a great deal of modern labour law and company law in common law systems such as the United Kingdom and the United States is statutory in origin. The idea that judge-made law is a 'spontaneous order' with adaptive properties, while the private law codes are constructivist restatements of the law which have restricted its development, draws far too strong a contrast between different regulatory styles. In practice, case law is subject to litigation strategies which incorporate pressure group activity in much the same way that legislation is (Galanter, 1974); the difference is one of degree, if it exists at all. In all systems, rules of legislative origin (including those originating in the private law codes, which are perhaps not accurately characterised as statutes at all) are subject to reinterpretation and ex-post adjustment by the courts in the light of the disputes that come before them. 
Having said that, there are good grounds for thinking that legal origins theory has identified in the legal system a potentially important source of path dependence in the evolution of market economies. In a weak-form version of the legal origin hypothesis, regulatory styles across national systems could have an impact on the content of substantive rules and, as a result, on economic outcomes, even if the questionable claim that the common law is inherently more likely to generate efficient results than the civil law is rejected. Systems theory or autopoiesis is useful here in pointing out the nature of, and limits to, the autonomy of the legal system with regard to the economy and to the political system (Teubner, 1993; Luhmann, 2006). The legal system, thanks to the development of its own distinctive discourse and processes, evolves according to an internal dynamic, and is not simply a cipher for broader economic or political forces. 'Legal culture', understood as the ingrained and often informal processes, concepts and understandings which aid the interpretation and application of legal rules, is a powerful force for preserving the distinctiveness of the legal order (Legrand, 1999; for examples in the labour law context, see Deakin, Lele and Siems, 2007). To speak of legal autonomy is not to imply that the legal system is unaffected by its wider context. Legal norms in an area such as labour law change over time in response, in part, to selective pressures coming from the external environment, and can be expected to influence the economic and political systems in their turn. The relationship between the legal and economic systems is recursive and iterative, rather than linear, but they are not completely sealed off from each other's influence. Rather than speaking of the legal system as entirely endogenous to the economy, it may be more accurate to invoke the idea of the coevolution of economy and law. Systemic coevolution ensures that, while the fit between systems is never exact, some degree of correspondence or congruence can be expected to take place over time, and for institutional complementarities to emerge. Thus the legal system may act as an institutional 'carrier of history', giving expression to conjunctions between political and economic institutions of the kind which the comparative political economy literature sees as a reason for the persistence of cross-national diversity (Ahlering and Deakin, 2007). 


\section{THE IMPLICATIONS OF VIEWING LABOUR MARKET INSTITUTIONS AS ENDOGENOUS}

How should we assess the debate about the economic impact of labour law in the light of these observations? We are moving away from a position which sees labour law as an exogenous interference with market relations, to one in which labour law rules are understood as evolved responses to coordination failures of various kinds. The evolution of labour law is a result, in the first instance, of the internal dynamics of the legal order, but is also broadly reflective of social practices in the areas which the law seeks to regulate. By virtue of its separation from the economy and the political realm, the law is never a perfect match for market conditions; it would only be completely adaptive if it ceased to be autonomous in any way. The separation of formal law from other social subsystems, while it carries a cost in terms of disjunctions between law and the economy, is also the precondition for the law's capacity to reproduce itself and thereby ensure the continuity of the collective learning which is embodied in legal norms (Carvalho and Deakin, 2008).

How far, then, can the law be used as an instrument of economic change? Here it is instructive to reflect on Teubner's striking observation that when the law imposes a wage freeze or (to use a more contemporary example, perhaps) enacts an unfair dismissal law, all that has happened, in one sense, is that there has been an internal communication from one part of the legal system to another (Teubner, 1993). What this means is that the legislative text itself, assuming it has been legitimately adopted, is recognized by the legal system as having certain effects for court judgments and rulings and associated mechanisms of legal enforcement. For example, the legislative articulation of a standard of fairness in dismissal has immediate repercussions for the underlying private law norms which, in most systems, impose few such formal constraints on the employer's power of termination. However, this says nothing about the implementation of the rule at the level of economic relationships. Such implementation depends on the capacity of the economic system to receive, de-code and implement the legal text, a process which goes on beyond the boundaries of the legal system. In practice, employment protection laws may be enforced and implemented by a variety of means: the activities of labour inspectors, human resources managers and trade 
union officials; litigation and other forms of dispute resolution; the adoption of codes of practice building on the law; the incorporation of legal norms into standard-form contracts at firm and industry level; and so on. The widespread acceptance of a legal rule may also come to depend on a general understanding on the part of market actors, without the need for specific enforcement mechanisms. However, only those legal norms which have an especially close connection to social practice and are based on a general consensus are likely to have this self-enforcing character. Many labour law rules, including unfair dismissal statutes, have distributive consequences which make them highly disputed in practice.

The effects of labour law depend, then, on the existence of processes beyond the legal system, referred to in systems theory as mechanisms of 'structural coupling', which serve to translate them, however imperfectly, into practice (Rogowski and Wilthagen, 1994). Under these circumstances, few a priori assumptions can be made about the impact of labour law rules. The impact of changes in formal rules at national level will depend on a range of factors in play at the level of the relevant industry or firm. At the micro level, the translation process may well be most problematic in precisely those sectors or enterprises which did not previously observe the social norm or practice from which part of the content of the rule is derived. The contentious application of unfair dismissal laws, which gave expression to the employment practices of large, bureaucratically-organised enterprises, to smaller firms and casualised forms of work illustrates the point. At a macro level, the impact of a labour law reform will depend on the knock-on effects upon complementary institutions. These are not confined to institutions of the labour market alone, but can extend to mechanisms which are closely linked to labour law, such as product market regulation, tort law, commercial contract law and, above all, company law and corporate governance (Barker and Rueda, 2007).

Is this essential indeterminacy of labour law one possible reason for the failure of empirical analyses to find a clear and consistent set of findings concerning its economic impacts? The predicted effects of employment protection legislation ('EPL') include higher unemployment as firms are deterred from hiring, and a reduction in productivity thanks to the slowing down of the movement of labour from less productive to more productive firms (Saint-Paul, 1997). On the other hand, EPL may reduce 
unemployment by making it more costly for employers to dismiss workers in a downturn, and by providing incentives for training as a substitute for redundancies it may enhance productivity (Koeniger, 2005). Empirically, it has proved very hard to establish which of these effects predominates. Econometric studies based on national-level data have not been able to establish a clear relationship between EPL and employment. There is some evidence that EPL stabilizes employment but also increases the duration of unemployment; evidence that it slows down the inter-firm movement of labour in response to demand and wage shocks is weak (see Bertola, 2008).

A nuanced view of the effects of labour law should take into account its selective impact; because the law is mostly concerned with extending and standardizing existing practices, legal interventions will have most impact on those firms and sectors which do not already follow the practices in question, or in which the workers most directly affected by the legal measure in question are concentrated. Taking this approach, Bassanini and Venn (2007), in an analysis of 18 OECD countries, report a negative relationship between EPL and labour productivity growth when 'EPLbinding' industries are compared to non-binding industries. They define an EPL-binding industry as one in which firms have a higher propensity to dismiss workers in a downturn. On the other hand, they find a positive impact of minimum wage laws on productivity in low-paying sectors, as well as a positive effect of parental leave laws in female-dominated industries.

A growing number of studies are looking at possible complementarities between labour law rules and alternative institutions including product market regulation and corporate governance rules (Boeri, Nicoletti and Scarpetta, 2000; Koeniger and Vindigni, 2003; Nicoletti and Scarpetta, 2003; Amable, Ersnt and Polombarini, 2005; Amable, Demmou and Gatti, 2007). Amable, Demmou and Gatti (2007), reviewing aggregate national data from OECD countries, find evidence to suggest that product market regulation and EPL are substitutes: deregulation in product markets produces higher growth only in conjunction with the preservation of a high level of EPL. Gatti (2008), conversely, finds that high EPL may be complementary to ownership concentration of the kind associated with a coordinated market approach to corporate governance: high ownership 
concentration has a positive impact on labour productivity when combined with high EPL.

This type of research, then, suggests that the impact of labour law changes must be assessed by taking into account both the uneven impacts which labour regulation has on firms and industries, and the way in which labour law interacts with other elements in the regulatory framework, with timeseries evidence being essential in both cases if dynamic effects are to be captured. When this is done, the economic effects of labour laws become certainly more complex but also, in many instances, more positive in terms of their implications for productivity and growth, than the standard approach implies.

For all that, the sway of the orthodox model remains strong, particularly at the level of policy making. In 2003 the IMF called for the deregulation of European labour markets, arguing that reforms intended to bring European labour laws into lines with those of the US would cut unemployment by over a third, with an even bigger reduction if they were combined with product market deregulation (IMF, 2003). The OECD, notwithstanding the ambivalence of some of its own empirical work on this point, has maintained the view that the deregulatory approach of its 1994 Jobs Strategy retains 'plausibility' (OECD, 2004: 165). The World Bank's Doing Business Report for 2008 states without equivocation that 'laws created to protect workers often hurt them' and that 'more flexible labour regulations boost job creation’ (World Bank, 2008: 19).

The core of the problem lies in the continuing use of the assumptions of orthodox theory to drive the analysis on which policy is based. The belief that the labour market, if left alone, will self-correct, is not simply the basis of the policy argument for deregulation, it also has methodological implications: 'adherents to the new orthodox view search the data for specifications/measures that support their priors, while barely noticing evidence that goes against them' (Freeman, 2005: 10). As Freeman suggests, one possible response to this approach is get better evidence of how labour laws operate at firm and industry level. He also points out that longitudinal evidence, which 'most empiricists would regard as providing a more valid and stronger test of any claim', is to be preferred to the crosssectional regressions on which the current orthodoxy rests (2005: 14-15). He also refers to the need to take into account the multiple institutional 
configurations which, in particular contexts, can alter outcomes, while also noting the difficulties inherent in studying these interactions empirically: there are some configurations for which no evidence is available; others may be found to be unique to single countries; and the relatively small number of countries for which good data exist, coupled with the slow rate of institutional change, mean that there may be relatively few data points compared to the number of possible institutional combinations.

\section{IDENTIFYING CORE HYPOTHESES AND RELEVANT EMPIRICAL METHODS}

We can sum up the discussion so far by identifying, in general terms, some core claims or hypotheses which come out of our theoretical review, and considering their implications for empirical research.

A first claim might be called the indeterminacy hypothesis; in other words, the economic effects of a given labour law reform are a priori indeterminate. This could be for various reasons: because labour law rules tend to emerge out of particular contexts, their effects will not be constant across all firms or industries; the application of labour regulations is dependent on a range of complex factors beyond the law which vary according to sectoral and national conditions, and to the point in the economic cycle at which legal changes are introduced; and, labour law rules can, in principle, have both positive and negative effects, which may offset each other. If all or some of these claims were correct, it would only be possible to predict the impacts of labour laws if a great deal were known about the contexts in which the relevant rules originated and in which they were applied. In an extreme form, the argument from indeterminacy becomes a claim about triviality: because of the endogeneity of of its emergence and the contingency surrounding its impact, it is unlikely that labour law can ever be a long-run causal factor independently influencing the path of economic development; at best it might be a cipher for other economic or institutional forces.

A second claim is the legal origins hypothesis advanced by Botero et al. (2004) in the labour law field. As we have seen, this holds that the content of labour law is determined to a significant degree by the legal 
origins of national systems. In the strong form of this hypothesis, the persistent effect of legal origin is an exogenous causal factor which is likely to lead to inefficiency, particularly in the civil law world and in systems into which norms are transplanted through copying, colonization of conquest. The weak-form hypothesis sees a link between legal origin and the content of laws but is sceptical on the efficiency implications of this.

A third claim is the complementarity hypothesis which can be derived from the comparative political economy literature. This maintains that the impacts of labour law rules depend upon the interaction of labour regulation with complementary institutions operating within particular national systems (or, by extension, at other relevant levels such as individual industries or transnational trading blocs). In particular, labour law rules might be expected to operate differently in liberal market systems and coordinated market systems, respectively. This set of claims overlaps to some degree with the other two. It shares with the indeterminacy hypothesis the view that labour law rules are at least partly endogenous to particular national or local contexts, without going so far as to imply that their effects are so radically contingent, or as trivial, as the indeterminacy approach suggests. It shares with the weak-form legal origins hypothesis an interest in legal infrastructure as a possible causal influence on economic development, but leaves open the possibility that the civil law 'regulatory style', for example, is complementary to the wider context of the coordinated market systems in which it mostly applies, and so compatible with efficiency (contrary to the strong-form legal origins hypothesis).

To test these claims, a more thorough empirical understanding of how legal systems operate is needed. As we have seen, the empirical literature is moving in the direction of studies which take into account a range of contextual effects relevant to the emergence and application of legal rules. There is also general agreement on the need to have better time-series data. It is with these points in mind that we now turn to have a closer look at recent developments in the evidence base relating to legal systems. 


\section{A CLOSER LOOK AT THE EVOLUTION OF LABOUR LAW SYSTEMS}

\section{A. Methodological issues IN LEGAL IndeX CONSTRUCTION}

A number of studies have recently developed measures of the intensity of labour regulation which have been used in cross-national empirical studies to estimate the impact of the law. One of the first of these was the OECD's EPL strictness indicator. This adapts an index first constructed by Grubb and Wells (1993). The index consists, in the first instance, of 18 items, which are grouped into three categories: rules affecting the dismissal of workers with 'regular contracts', a term which refers to contracts of employment of indeterminate duration; rules relating to fixedterm and temporary (agency) contracts; and regulations, over and above those in the first two categories, governing collective dismissals. The information contained in the 18 items is drawn, in the first instance, from accounts of the formal laws in force in 28 OECD member states. Scores are assigned on a number of bases, which include the length of time it takes to give notice of dismissal and the number of months of mandated severance pay; in other cases, ordinal scales are used, for example, to indicate the strictness of the legal tests for judging the fairness of dismissal. The scores are standardized and expressed on a scale from 0 to 6 , with 6 representing maximum strictness. Once the values for individual variables are set in this way, they are aggregated into a smaller number of units, which are weighted and combined again to form three indicators representing the strictness of regulation of regular contracts, temporary contracts and collective dismissals. Finally, an overall indicator of strictness for each country is arrived by combining the three main indicators, with collective dismissals weighted at $40 \%$ of the other two (on the basis that this indicator covers rules operating over and above those which are captured by the first two indicators).

The data contained in the OECD index cover three points in time, corresponding to the three main data-gathering exercises which the OECD has conducted: the late 1980s, the late 1990s, and 2003. The collective dismissals indicator was only introduced in the 1999 exercise, so two versions of the overall indicator exist: version 1, covering the rules 
governing regular and temporary contracts only (without the rules on collective dismissals), goes back to the first exercise in the 1980s, while version 2, with the addition of the collective dismissal rules, only covers the last two exercises. A detailed account of the laws in force in 2003 has been provided and justifications offered for the scores arrived at. Changes in the law which took place in between the three main data gathering exercises have also been collected, so that it becomes possible to construct an annual time series.

The authors of the OECD index accept that it suffers from limitations which are 'inherent to most synthetic indices' and which include 'problems of subjectivity, the difficulty of attributing scores on the basis of legal provisions that may be applied differently in practice, and the choice of the weighting scheme used to calculate the summary indicator form from the various sub-components' (OECD, 2004: 99). Steps have been taken to address some of these issues, but some remain intractable. The index takes into account, for example, benefits set out in collective agreements and contractual practices which are widely followed in some countries, such as Japan, where their operation is well documented, but for some countries there are no reliable data on these issues. The role of judicial interpretation is also noted along with aspects of court procedure which can affect the enforcement of rights. Evidence on court practice has been collated and is reflected in the scores given to some of the variables on unfair dismissal remedies (OECD, 2004: 66).

Some patterns emerge from the OECD data on the state of the law. There is a wide variation across countries which is mainly accounted for by differences in the regulation of temporary and fixed-term contracts; there has, however, been a degree of convergence since the early 1990s, largely as a result of deregulation, although this has been limited. The rankings of countries has changed very little over time, with the so-called AngloSaxon systems having the lowest scores, those in southern Europe having the highest, with the northern European and Nordic systems in the middle.

Cross-sectional, bivariate analyses reported in the 2004 OECD Employment Outlook indicate a link between EPL strictness, as measured by the OECD index, and flows into and out of unemployment, although the association is weak (in relation to the 2003 data gathering exercise the relationship between EPL strictness and flows out of unemployment is 
negative but not statistically significant). There is no consistent relationship either way with unemployment. The 2004 Employment Outlook accepts that bivariate and time-specific analyses of this kind can only provide limited information and should not be used to guide policy. It therefore reports additional tests which take advantage of the time series of EPL strictness which has been constructed in the way just described. When this is done, a correlation between EPL and higher unemployment is established, and there is evidence of a negative impact of EPL on unemployment flows. The changes in EPL which took place over the course of the 1990s, which mainly consisted of relaxations to the laws governing temporary and fixed-term work, are correlated with an increase in the adoption of temporary and fixed-term contracts (OECD, 2004: 79).

The other main indicator of labour regulation which is currently in use is the 'employing workers index' of the World Bank, which is published annually in its Doing Business reports. This builds on the labour regulation index drawn up by Botero et al. (2004) and is one of the series of indicators developed by the members of legal origin school. The index prepared by Botero et al. has a wider scope than the EPL strictness indicator as it covers not just employment protection but other areas of labour law, including strike law and the law of employee representation, as well as aspects of social security legislation, including unemployment insurance. It also extends to a wider range of both developed and developing countries. The index contains over 100 indicators each of which is defined according to an algorithm which sets out the basis for the coding. The resulting scores (which are mostly expressed on a zero to 1 scale) are normalized and averaged to produce composite variables on particular areas of law. For example, the indicator 'cost of firing workers' is built up from six sub-units which code the law on such matters as the mandated length of notice period, the mandated severance pay, and so on. The resulting composite variable measures the cost of firing 20 per cent of the firm's workforce, ' $10 \%$ for redundancy and $10 \%$ without cause'. The following assumptions are made:

'The cost of firing a worker is calculated as the sum of the notice period, severance pay, and any mandatory penalties established by law or mandatory collective agreements for a worker with three years of tenure with the firm. If dismissal is illegal, we set the cost of firing equal to the 
annual wage. The new wage bill incorporates the normal wage of the remaining workers and the cost of firing workers. The cost of firing workers is computed as the ratio of the new wage bill to the old one.' (Botero et al., 2004)

This variable is then aggregated with others ('alternative employment contracts', 'cost of increasing hours' and 'dismissal procedures') to produce a single indicator for 'employment laws'. Similar procedures are used to arrive at scores for 'collective relations laws' and 'social security laws'. The three sub-indices can then be combined to produce a single country score.

The Botero et al. index simply cites as its main source 'the laws of each country'. A number of more specific sources of general relevance to labour law are referred to, including legal encyclopaedias and compendiums of social security laws, but, in contrast to the OECD's index of EPL strictness, no explanations are given for the values attributed to the basic informational units at country level. The index is purely crosssectional: it reports the state of the law at a loosely-defined point in the late 1990s.

The main finding of the analysis carried out by Botero et al. (2004) was that labour regulation is highly correlated with legal origin, with systems in the French civil law family having the highest scores and those in the English common law family the lowest. On the basis of cross-sectional bivariate analyses the study also reports negative impacts of labour regulation. Higher scores on the index are correlated with lower male employment, higher youth unemployment, and a larger informal economy. However, the correlations are not consistently strong or significant (see Pozen, 2006, for a critique). Because the index is cross-sectional, it cannot be used to study the effects of changes in labour law regulation over time, nor can it capture dynamic interaction effects of the kind hypothesized in the comparative political economy literature.

The World Bank's employing workers index adopts the methodology of Botero et al. (2004) but has a somewhat different content. It is built up from three sub-indices: a 'rigidity of employment index', an index of nonwage labour costs, and one which measures firing costs. The rigidity of 
employment index contains sub-indices, covering 'difficulty of hiring', 'rigidity of hours' and 'difficulty of firing'. These are broken down again, so that the difficulty of hiring index, for example, measures '(i) whether fixed-term contracts are prohibited for permanent tasks; (ii) the maximum cumulative duration of fixed-term contracts; and (iii) the ratio of the minimum wage for a trainee or first-time employee to the average value per worker'. As in the original Botero et al. study, definitions of the base units are set out and protocols established for coding. Values are expressed as scores between 0 and 100, with 100 representing 'more rigid regulation'. Countries are ranked on the basis of their scores.

The sources on which the index is based are stated to be 'a detailed survey of employment regulations that is completed by local lawyers and public officials'; laws, regulations and secondary sources 'are reviewed to ensure accuracy' (World Bank, 2008). The index is in the form of a time series which is updated each year; it begins in 2004, taking advantage of the regular survey administered by the World Bank, but there has been no attempt to code laws further back than this.

A principal feature of the World Bank index, building on Botero et al. (2004), is that while it is based largely on textual evidence of formal laws, supplemented by survey results on perceptions of regulatory stringency, it tries to capture actual costs as they impact on firms. More precisely, the evaluations of the effects of laws are assumed to measure their impact on a particular category of worker (a middle-aged, male, full-time employee with 20 years service in the same company earning the company's average wage and not a member of a trade union, unless membership is mandatory) and a particular type of firm (which among other things is a limited liability company located in the country's capital city, 100\% domestically owned and employing just over 200 employees (World Bank, 2008b)). These may, in a sense, be 'standard' cases as they represent the contexts to which labour law regulations most easily apply and for which many of them were initially designed. However, they are not in any sense representative cases, particularly in many developing countries where only a small proportion of the overall working population will fit this description. But even in developed systems where 'standard' work in large manufacturing firms remains widespread, World Bank index will not capture the extent to which labour law rules are modulated in other contexts, such as those involving small and medium-sized 
enterprises. The World Bank index has chosen to focus not on an average case but on one in which the law is at its most protective or, in the World Bank's own terms, most 'rigid' (Berg and Cazes, 2007; Lee and McCann, 2007). It cannot even be assumed that, in the 'standard cases' on which the employing workers index is based, an accurate assessment of actual costs can be gauged from the combination of legal texts and survey evidence on which the index relies. The index is based on the assumption that the firm in question 'abides by every law and regulation but does not grant workers more benefits than mandated by law, regulation or (if applicable) collective bargaining agreement' (World Bank, 2008b). Thus no account is taken of the degree to which the 'standard' firm already observes the standards set out in the law, or, in practice, exceeds them. 'Standard' firms are precisely those which are most likely to do both. For these various reasons, it is difficult to avoid the conclusion that the World Bank index is not, as it purports to be, a measure of actual costs.

\section{B. NEW TIME SERIES EVIDENCE: THE CBR INDICES ON SHAREHOLDER PROTECTION, CREDITOR RIGHTS AND LABOUR REGULATION}

A set of longitudinal indices on the evolution of company, insolvency and labour law has been developed over the past three years by a team of economists and lawyers at the Centre for Business Research ('CBR') in Cambridge. The aim of this project has been (among other things) to examine the claims of the legal origin hypothesis, using time series evidence. The nature of the CBR datasets will now be briefly explained; more complete accounts are available elsewhere and the reader is referred to these papers (see Lele and Siems, 2007; Deakin, Lele and Siems, 2007; Armour et al., 2007) and to the project home page, where the indices are available on

line (http://www.cbr.cam.ac.uk/research/programme2/project2-20.htm), for a fuller explanation.

The CBR datasets cover the development of the law in five countries (France, Germany, India, the UK and the US) over the period 1970-2005 using a wide range of indicators which are intended to provide a comprehensive map of the law in the areas under review. Datasets have 
also been constructed for a larger number of countries over a shorter period of time (1995-2006), focusing on a sub-sample of legal variables which is weighted so as to capture the state of the law in undergoing the most rapid change. In this paper we will focus on the datasets covering the longer period, and look at the experience of the four developed systems in the sample, namely France, Germany, the UK and the US. ${ }^{1}$

The CBR's labour regulation dataset draws on methods first used in the OECD and World Bank studies, but modifies them in ways which are intended to address some of the methodological problems which were encountered in the construction of those datasets. The CBR index for labour regulation contains 40 basic variables which are aggregated into five areas: alternative employment contracts, regulation of working time, regulation of dismissal, employee representation, and industrial action. As in the case of the Botero et al. index, an algorithm is prepared setting out the definition of each variable and the approach to the way the law of each country is coded; as with the OECD, detailed explanations are given of the basis for the codings, and the legal sources relied on are fully set out. These are the primary legal sources, rather than the summary descriptions of legal rules provided by the OECD.

The CBR index differs from its predecessors in two main respects. Firstly, it aims to reflect the systemic nature of legal rules, that is, the sense in which the function of a given legal rule alters according to the nature of its structural relationship to other legal and non-legal rules in a given national context. While, in broad terms, legal rules relating to the business enterprise can be understood to perform certain functions of general relevance in market economies, across national systems it is by no means the case that the same formal rule always performs the same function. The relevant rule can often be found outside the legal system altogether. It follows that when thinking about rules as functional equivalents, it is necessary to look beyond the formal law (Zweigert and Kötz, 1998). Thus the CBR index takes into account collective agreements and, in the case of the shareholder protection index, corporate governance codes of practice,

1 The CBR dataset also covers India (see Deakin, Lele and Siems, 2007). India raises special considerations when analysing the economic impact of legal rules, because of the issue of the enforcement of labour laws, and the large informal sector. Accordingly we leave the analysis of the Indian case for future research. 
in addition to formal legal rules, where they can be considered as functional equivalents to legal rules. An example of this is the coding of sector level collective agreements on working time in the UK which, thanks to the equivalent of extension legislation, operated as a de facto floor of rights up to the 1980s, when this form of statutory prop for collective bargaining was withdrawn and the collective agreements themselves began to break up. Secondly, and relatedly, the CBR index attempts to capture variations in the degree of bindingness of legal rules. Specifically, this means taking into account the form of labour law rules, many of which are not mandatory at all but operate as default rules which can be varied by individual or collective agreement. The index also seeks to capture the extent to which labour standards can be modified for particular types of enterprise or work relationship. On the whole, graduated variables are preferred to simple binary scores of dummy variables.

To illustrate in more detail the way in which the index was constructed, the Appendix sets out the part of it which refers to dismissal laws in the United Kingdom. This sub-index on the regulation of dismissal contains nine variables, which cover matters ranging from the rules on legally mandated minimum notice periods to the law governing priority in reemployment. The Table sets out the algorithm according to which each variable is defined, the score given to the law for each year in the period covered by the index, and the explanation for the coding. The complete codings, covering all forty variables for the full range of years and countries in the dataset, may be consulted online. ${ }^{2}$

It follows from the account of the construction of the index which has just been given that it does not purport to estimate the actual impact of labour law rules on a representative enterprise. As we have seen, attempts to do this run up against some fundamental difficulties which are likely to render the results excessively artificial. The CBR index sets out, more straightforwardly, to measure the extent of regulation, understood as the degree to which a rule protects the interests of workers as opposed to those of employers, using as a benchmark a scale set out in an algorithm developed for this purpose.

2 See http://www.cbr.cam.ac.uk/research/programme2/project2-20.htm. 
Does this not produce an even more artificial set of results than those of the World Bank, which at least attempt to get beyond the formal legal rules by incorporating estimates of actual costs and which incorporate the possibility of non-enforcement by obtaining survey evidence on perceptions of regulation? Our response to this point is that it is preferable not to try to measure actual costs at enterprise level by means of a synthetic index of this kind: it is better to accept that this is impossible given the wide range of contexts in which labour law rules apply and the multiplicity of factors through which formal rules are mediated when they are observed and applied at micro level. Moreover, having an index of formal rules does not rule out taking steps to look at actual effects. It is possible to control for the non-application of laws in practice, or for their non-enforcement, by using measures of institutional effectiveness such as the World Bank's rule of law index (see Armour et al., 2007). Alternatively, indices based on the formal strength of laws can be amended in the light of evidence of their implementation, as in the case of the index of the effective observance of working time laws constructed by Lee and McCann (2007). At the same time, having a measure of the formal law which is not, in itself, qualified by issues of enforcement, can be useful for other purposes, for example in seeing to what extent formal legal changes are correlated with 'upstream' influences on the political process such as interest group coalitions or macroeconomic shocks.

In the case of the four countries studied here, all of which are developed economies with well functioning legal systems, it may be assumed that labour laws are, on the whole, well observed. This is not to say that enforcement is always effective or that it is entirely uniform across these four systems, or within each of them; however, any enforcement difficulties are of a different order to those affecting some developing systems for which it would be appropriate to make use of indices which seek to capture the effectiveness of the legal system.

A further feature of the CBR index is that, in its construction, no prior assumptions, positive or negative, are made about the impacts of legal rules. It seeks to be a pure measure of the content of the rule which does not assume that the law necessarily imposes on employers net 'costs' or 'rigidities', to use the language of the World Bank, or that increasing regulation is necessarily associated with increasing 'strictness', as the OECD puts it. As we have seen, labour law rules can have positive 
economic effects, and employers, as well as workers, may benefit from the use of the law to solve collective action and coordination problems. In case of the OECD and World Bank scales, it is assumed that a higher score necessarily equates to an undesirable outcome for the employer, and a lower score to a better outcome. The highest score is assumed to be the worst possible outcome for the employer and the lowest score the best. No such assumption is made in the CBR scales: it is possible to have too high, but also too low a level of regulation, for both employers and workers. The precise level of the 'optimal' score is not known a priori, on the basis that it will most likely differ from system to system, and that it is the purpose of the index to chart this variation as far as possible.

The World Bank index has been criticized because its indicators 'do not consider the positive externalities of labour regulations' (Berg and Cazes, 2007: 6). The algorithms used by the World Bank studies repeatedly refer to 'costs' and 'rigidities' being imposed on employers as a result of regulation, and nowhere refer to potential benefits. In itself, this might not prevent the index being shown to be correlated to positive outcome variables; the same point applies to the OECD index. The issue is whether, given their theoretical priors, these indices exhibit a systematic bias in their choice of variables and weightings which make such a result unlikely. This is not altogether clear; in its favour, the Botero et al. index correlates well with evidence of the perceptions of the strength of labour law regulation drawn from a large-scale survey which included trade union officials and labour law academics as well as employers (Chor and Freeman, 2005). Perhaps the best that can be said is that given the theoretical assumptions driving this index, it is noteworthy that its empirical analysis does not give a very clear picture of the supposed negative effects of labour law (see Pozen, 2006).

The CBR index does not solve all the problems associated with index construction. Every index contains an implicit weighting, in so far as a decision has to be taken either to weight each variable equally, or to alter the weighting to reflect a view of their comparative importance. This can be done country by country, given that it is unlikely, in principle, that the same law has the same systemic importance in each system; codetermination laws, for example, might be thought to play a pivotal role in Germany which would justify weighting employee representation scores more heavily in an overall assessment of the intensity of labour law 
regulation in that country than would be the case in France or the UK (see Ahlering and Deakin, 2007). While weighting of this kind can be done, we have chosen not to weight the variables in the CBR index for the purposes of the present analysis, largely because it is not clear that this can be done on an objectively verifiable basis (see the discussion in Deakin, Lele and Siems, 2007). The OECD's EPL strictness indicator uses weightings extensively when aggregating the individual informational units into composite indicators; many of weightings are not explained and not self-evidently justified. Botero et al. (2004), by contrast, make no attempt at a priori weightings, and we follow their approach here.

As we have seen, all synthetic indices of this type involve some degree of subjective judgment on the scores attributed to particular variables. The issue is not whether each individual score is beyond dispute, since there will always be some scope for disagreement among legal scholars and others about the precise value to be attributed to a given variable, but whether the coding is consistent across countries and across time (Spamann, 2007; Berg and Cazes, 2007). This means constructing the variables so as to avoid selection biases which might, for example, skew the outcomes either for or against a particular system. It is possible, for example, that the CBR labour regulation index suffers from a countryspecific bias, in so far as the inclusion of variables on the equal treatment of part-time and temporary work reflect laws of the kind which are found in European Union countries (thanks in part to individual country traditions and also to the harmonizing impact of EU directives) but virtually nowhere else, and in particular not in the US case. We have sought to mitigate this problem by defining the relevant variables in functional, country-neutral terms, and in judging how far, from the operation of other forms of regulation such as laws governing basic labour standards, US law permits the differential treatment of part-time or fixedterm workers. It is also possible to object to the CBR index on the grounds that the choice of variables will, in and of itself, unduly depress the US score, simply because of the absence of unjust dismissal legislation in that system. This is undeniably a problem, but another way of looking at the issue is simply to accept that US laws on employment at will, by their nature, imply a much lower score on these variables than the scores for the European countries in the sample. 


\section{STATISTICAL ANALYSIS OF THE IMPACT OF LABOUR REGULATION}

It is now time to turn to the analysis. What can we learn from a first look at the long-term time series provided by the CBR datasets?

We first look at the degree of covariance in the level of protection across the four countries and the extent of their divergence or convergence over time. Figure 1 indicates that France and Germany had a considerably higher degree of regulation than the other two systems throughout the period in question. Legal origin also seems to make a difference. As Table 1, Part I shows, the difference between the common law systems and the rest was substantial and statistically significant in respect of the index as a whole and each of its main component parts.

In itself, this does not establish that legal infrastructure is responsible for diversity of practice. It is not possible directly to observe aspects of legal infrastructure, such as the respective role of courts and legislatures, in the dataset. The observed divergence may be compatible with the weak-form legal origins effect, in which legal systems serve as 'carriers of history' to perpetuate institutional complementarities arising at national level, but are not themselves the root cause of such conjunctions (Ahlering and Deakin, 2007). 


\section{Figure 1}

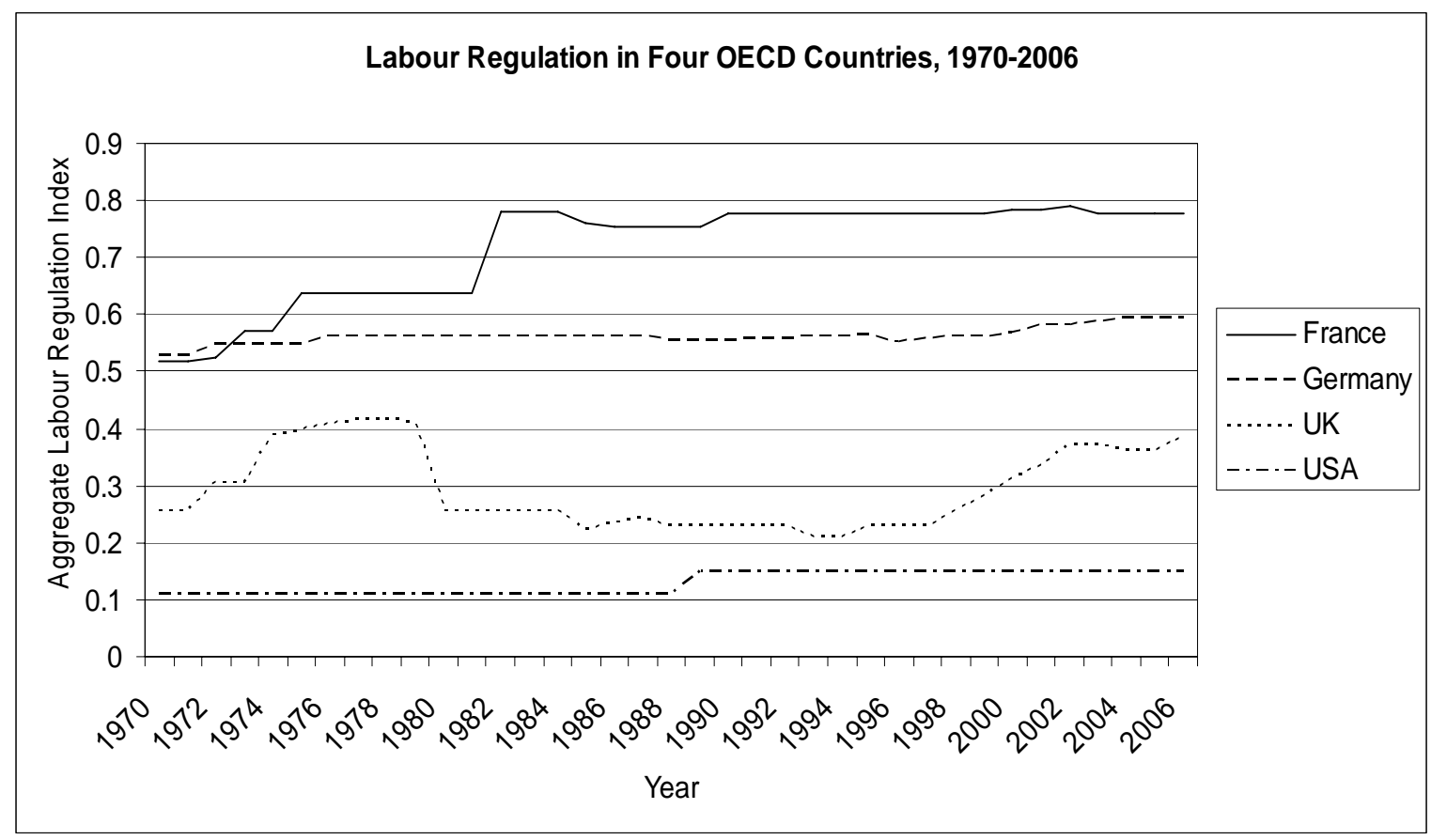

Source: CBR Labour Regulation Dataset (Deakin, Lele and Siems, 2007; http://www.cbr.cam.ac.uk/research/programme2/project2-20.htm).

Table 1

Regression Analysis of Labour Regulation in Four OECD Countries since 1970

\begin{tabular}{|l|c|c|c|c|}
\hline \multicolumn{1}{|c|}{ Series } & a & Eng & t & R-Sq \\
\hline $\begin{array}{l}\text { I. Panel Data } \\
\text { Analysis }\end{array}$ & & & & \\
\hline (i) All (RE) & $0.64^{* * *}$ & $-0.43^{* *}$ & & 0.83 \\
\hline $\begin{array}{l}\text { (ii) Alternative } \\
\text { employment } \\
\text { contracts (RE) }\end{array}$ & $0.74^{* * *}$ & $-0.5^{* * *}$ & & 0.76 \\
\hline (iii) Regulation of & $0.66^{* * *}$ & $-0.5^{* * *}$ & & 0.86 \\
\hline
\end{tabular}




\begin{tabular}{|c|c|c|c|c|}
\hline working time (RE) & & & & \\
\hline $\begin{array}{l}\text { (iv) Regulation of } \\
\text { dismissal (FE) }\end{array}$ & $0.57 * * *$ & $-0.34 * * *$ & & 0.5 \\
\hline $\begin{array}{l}\text { (v) Employee } \\
\text { representation } \\
\text { (RE) }\end{array}$ & $0.61 * * *$ & $-0.45 * * *$ & & 0.73 \\
\hline $\begin{array}{l}\text { (vi) Industrial } \\
\text { action (RE) }\end{array}$ & $0.62 * * *$ & $-0.38 * * *$ & & 0.53 \\
\hline $\begin{array}{l}\text { II. Trend } \\
\text { Analysis of } \\
\text { Coefficients of } \\
\text { Variation }^{2}\end{array}$ & & & & \\
\hline (i ) All [AR (1)] & $70.004 * * *$ & & -0.02 & 0.79 \\
\hline $\begin{array}{l}\text { (ii) Alternative } \\
\text { employment } \\
\text { contracts [AR (1)] }\end{array}$ & $84.67 * * *$ & & $-0.84 * *$ & 0.82 \\
\hline $\begin{array}{l}\text { (iii) Regulation of } \\
\text { working time [AR } \\
\text { (1)] }\end{array}$ & $68.51 * * *$ & & 0.8 & 0.81 \\
\hline $\begin{array}{l}\text { (iv) Regulation of } \\
\text { dismissal [AR (1)] }\end{array}$ & $90.64 * * *$ & & $-1.36 * * *$ & 0.64 \\
\hline $\begin{array}{l}\text { (v) Employee } \\
\text { representation } \\
\text { [AR (1)] }\end{array}$ & 62.38 & & 0.94 & 0.84 \\
\hline $\begin{array}{l}\text { (vi) Industrial } \\
\text { action [AR (1)] }\end{array}$ & $53.43 * * *$ & & $0.72 *$ & 0.85 \\
\hline
\end{tabular}

*** $\quad$ Significant at 1 per cent level.

** $\quad$ Significant at 5 per cent level.

* $\quad$ Significant at 10 per cent level.

1 The following panel regression has been fitted:

$$
\mathrm{Y}=\mathrm{a}+\mathrm{b} . \text { Eng }
$$

where $\mathrm{Y}$ is the series on legal protection , Eng $=1$ for UK and USA and $=0$ for France and Germany. Results reported here are either based on the random effects (RE) or fixed effects (FE) model depending on the outcome of BreuschPagan test. The particular model used is referred to in parentheses. In each case both the models give more or less the same result.

2 The following trend regression has been fitted: 
$\mathrm{Y}=\mathrm{a}+\mathrm{b} . \mathrm{t}$

where $\mathrm{Y}$ is the series on coefficient of variation in different aspects of legal protection in two legal groups - English Law and Civil Law - and t is the time trend. The procedure for arriving at the estimates is referred to in each column; it is AR (1), decided on the basis of Lagrange multiplier test of autocorrelation.

Source: CBR Labour Regulation Dataset (Deakin, Lele and Siems, 2007; http://www.cbr.cam.ac.uk/research/programme2/project2-20.htm).

If we were observing the strong-form legal origin effect, we would expect it to be a consistently powerful constraint on convergence. We do not observe a time-invariant effect of this kind. The overall picture is one of convergence between common law and civil law systems during the 1970s, followed by sharp divergence in the early 1980s and some convergence again in the following years (see Figure 2). More formally, Table 1, Part II reports the findings of a trend analysis (taking into account the problem of auto-correlated residuals) of the time series of the coefficients of variation (standard deviations as percentages of the mean) in the different components of the index, breaking down the sample of countries by legal origin (English law and civil law). Changes in the coefficient of variation over time can be used to provide a measure of the extent of convergence and divergence between systems, with a lower score indicating greater convergence. The evidence in Figure 2 and Table 1 show that there is no statistically significant converging trend for the aggregate index over the whole period of our study. This is also true of the sub-indices for regulation of working time employee representation: these show a once-and-for-all diverging jump in the early 1980s and a slow trend to convergence in the early 2000s. However, regulations on alternative employment contracts and regulation of dismissal show statistically significant converging trends. The sub-index on the regulation of industrial action shows divergence since the early 1980s and a more recent tendency towards convergence; across the entire period, there is an overall diverging trend which is barely statistically significant (see Table 1, Part II, rows i-vi). 
Figure 2

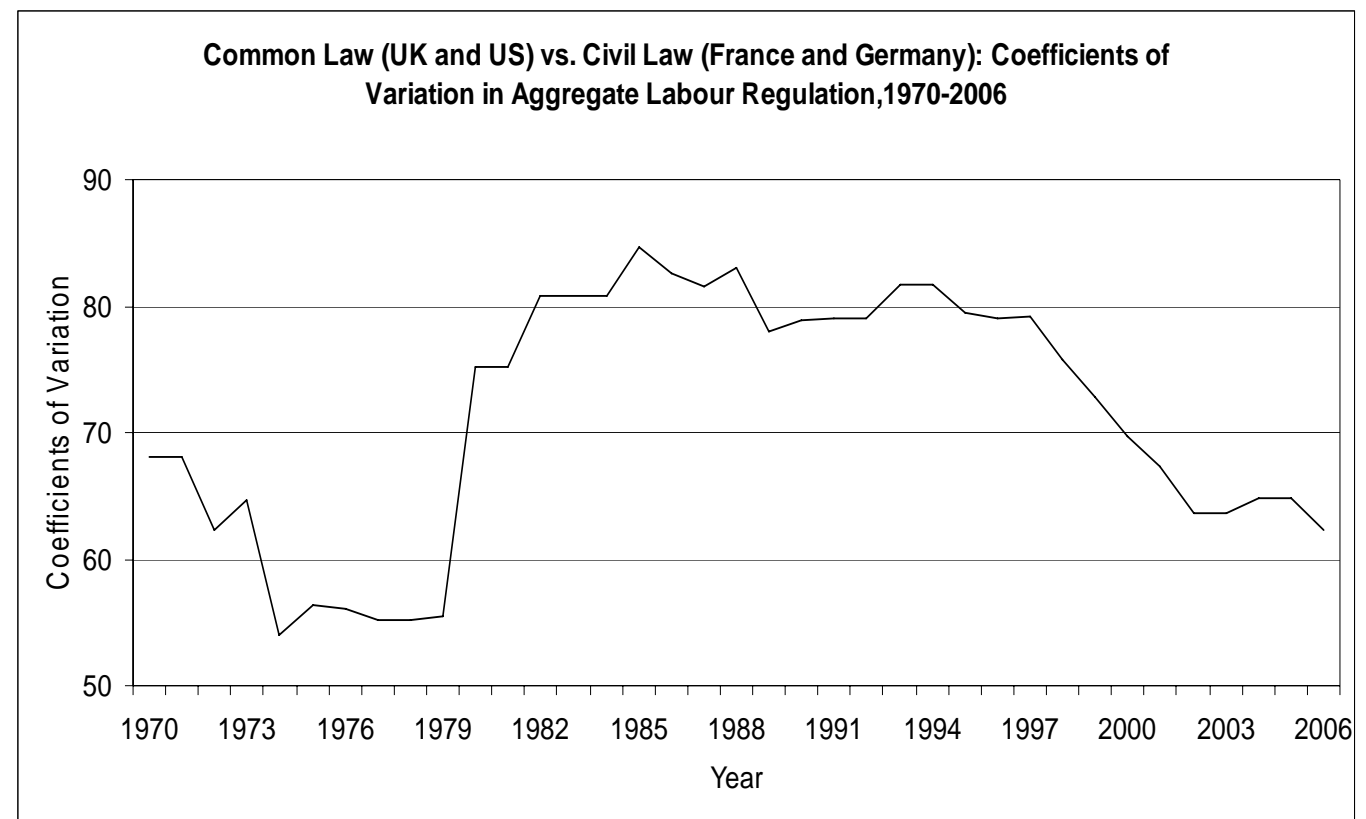

Source: CBR Labour Regulation dataset (Deakin, Lele and Siems, 2007; http://www.cbr.cam.ac.uk/research/programme2/project2-20.htm).

There is then, some support for the legal origin hypothesis, but it is qualified. Unlike the cases of the law governing shareholder protection and creditor rights, where analysis of the equivalent CBR datasets reveal no clear pattern of regulation at all by reference to the common law or civil law divide (see Armour et al., 2008), here there is one. Legal origin therefore appears to matter for labour law in a way it does not for company law and insolvency law. However, when we look more closely at the labour law findings, the picture gets cloudier. There is some evidence of convergence, legal origin notwithstanding, in the areas of dismissal law and the regulation of the law governing alternative contracts of employment. This represents the partial convergence of British labour law on the unfair dismissal model which is, historically, much more deeply rooted in the experience of the civil law countries, France and, in particular, Germany. The UK adopted unfair dismissal for the first time in the early 1970s, and since the mid-1970s has more or less kept intact this 
form of regulation. ${ }^{3}$ Weakening of the legislation in the mid-1980s reflects the lengthening of qualifying periods and related changes to the coverage of the law, but this trend was reversed in the 1990s, when EU law led to the removal of hours thresholds which discriminated against part-time workers. Since the mid-1990s there has been a considerable alignment of UK practice on the regulation of alternative forms of the employment contract, which has come about thanks to the adoption of the EU directives on the rights of part-time and fixed-term contract workers.

Common law legal origin did not prevent the UK from adjusting to a type of legislation which had continental European origins. The initial impetus for this process did not come from the EU; the UK first adopted unfair dismissal legislation in 1971, under a Conservative government, and at a point when there were no European directives in force on labour law issues. There still is no directive requiring general unfair dismissal legislation across the EU. The rapprochement of UK law with European standards on flexible forms of employment which has taken place since the mid-1990s is the result of the implementation of EU directives, as is the revival of working time regulation, which nevertheless remains below the level which prevailed at the end of the 1970s when sector collective agreements on working hours were still in force. Notwithstanding some limitations in the UK model, its framework of individual employment law is now significantly closer to that of Germany and France than it was a decade ago. There remains a much more substantial gap in relation to collective labour law. Since the mid-1990s the closed shop has not returned nor have there been major changes in strike law (aside from a strengthening of the right not to be dismissed when taking lawful strike action); there has, however, been some strengthening of the law governing employee representation, as a result, again, of the implementation in the UK of EU directives in this area.

The role of political shifts in the development of the law can be seen from the data. The big jump in the regulation of dismissal law, working time and employee representation which occurred in France in the early 1980s

3 As noted above, full details on this and other aspects of changes in labour law in the four countries concerned set out in the text are available on the CBR website along with the dataset: http://www.cbr.cam.ac.uk/research/programme2/project2-20.htm. 
took place under the Auroux laws of the first Mitterand government. At the same point, the Thatcher government was removing working time controls and reversing legislation supporting the closed shop and the right to strike, although it made hardly any changes to unfair dismissal law. This turning point aside, it is hard to point to strong political pressures as the cause of change. Conservative French governments throughout the period under review have made little impact on the high level of labour law regulation achieved by the 1980s reforms; changes to working time legislation, for example, have been relatively minor, and have mostly taken the form of converting mandatory standards into default rules and extending the role of collective bargaining at the expense of binding legislation. In Germany, there has been a high level of political consensus across the period as a whole. The limited deregulation of aspects of dismissal law which was part of the Hartz reforms of the 2000s was brought about by a social democratic-led administration. All this suggests that when partisan politics directly influences the direction of legal change, it tends to do so through once-and-for-all adjustments of the kind experienced in Britain and France in the early 1980s; the more normal pattern is one of cross-party consensus on labour law matters.

The level of protection for workers provided by US law during the period is not only well below that of the other three countries; it is also relatively unchanging. This does not necessarily represent a political consensus on labour law matters, but it does reflect the logjam on legislative reform which has operated at federal level. The scores in the index were not altered to reflect changes in the law governing employment at will in some states. In principle, changes in the law at state level can be captured in the dataset if they are significantly widespread and affect more populous states (see Deakin, Lele and Siems, 2007). However, the changes which took place were negligible when set against the much more rigorous legal standards governing termination of employment in Europe. Thus they are not regarded as significantly affecting the national picture. ${ }^{4}$

4 In this regard, we take the same view as the authors of the OECD EPL strictness indicator, and Botero et al. 2004. It is arguable that we should take into account the likelihood that the proportion of American workers covered by a justcause provision of some kind is as high as 34\% once collective agreements in both the public and private sector are taken into account, along with contractual provisions governing termination (Verkerke, 2008). However, these agreements 
What can we say about the economic impacts of legal change? It is possible to undertake a time series analysis, looking at the relationship between changes in the values in the legal time series, with long-run movements in employment, productivity and redistribution. The results are set out in Table 2 .

Table 2

Labour Regulation, Employment, Real Output and Wage Share in Four OECD Countries, 1971-2006: Regression Analysis

\begin{tabular}{|l|l|}
\hline Dependent & -: Regressors: - \\
Variables/ & \\
Countries/ & \\
\hline
\end{tabular}

\begin{tabular}{|c|c|c|c|c|c|c|}
\hline & $\begin{array}{c}\mathrm{a} \\
\text { (intercept) }\end{array}$ & $\begin{array}{l}\text { DLRDGP } \\
\text { (real GDP } \\
\text { growth rate) }\end{array}$ & $\begin{array}{l}\text { LR } \\
\text { (Labour } \\
\text { Law } \\
\text { Index) }\end{array}$ & $\begin{array}{l}\text { Adj. } \\
\mathrm{R}^{2}\end{array}$ & $\begin{array}{l}\text { Durbin- } \\
\text { Watson } \\
\text { Statistic }\end{array}$ & Process ${ }^{\star}$ \\
\hline \multicolumn{7}{|c|}{$\begin{array}{l}\text { (A) Growth of } \\
\text { Civil } \\
\text { Employment } \\
\text { (DLN) }\end{array}$} \\
\hline & & & $\begin{array}{l}A L L \\
\text { (variables } 1 \text { to } \\
40 \text { ) }\end{array}$ & & & \\
\hline France & -0.02 & $0.36^{* * *}$ & 0.02 & 0.65 & 1.86 & AR (1) \\
\hline Germany $^{1}$ & -0.21 & $1.31^{* * *}$ & 0.34 & 0.18 & 2.22 & OLS \\
\hline UK & -0.004 & $0.37 * * *$ & -0.003 & 0.48 & 2.15 & AR (2) \\
\hline \multirow[t]{2}{*}{ USA } & $0.04 * *$ & $0.11^{* * *}$ & -0.21 & 0.51 & 2.06 & AR (1) \\
\hline & & & $\begin{array}{l}\text { Alternative } \\
\text { employment } \\
\text { contracts } \\
\text { (variables } 1 \text { to } 8 \text { ) }\end{array}$ & & & \\
\hline France & $-0.12 * * *$ & $0.35 * * *$ & 0.008 & 0.67 & 1.85 & AR (1) \\
\hline
\end{tabular}

and provisions mostly operate at individual employer level; they are not the result of legally-binding multi-employer agreements which, in the case of UK working time regulation up to the late 1970s, could be regarded as the functional equivalent of legislation, and were coded accordingly. 


\begin{tabular}{|c|c|c|c|c|c|c|}
\hline Germany $^{1}$ & -0.26 & $1.31^{* * *}$ & 0.33 & 0.2 & 2.23 & OLS \\
\hline \multirow[t]{2}{*}{ UK } & -0.007 & $0.37 * * *$ & 0.01 & 0.51 & 2.16 & AR (2) \\
\hline & & & $\begin{array}{l}\text { Regulation of } \\
\text { working time } \\
\text { (variables } 9 \text { to } \\
\text { 15) }\end{array}$ & & & \\
\hline France & $-0.13^{* *}$ & $0.36^{* * *}$ & $0.17 * *$ & 0.69 & 1.89 & AR (1) \\
\hline Germany $^{1}$ & -0.19 & $1.34^{* * *}$ & 0.31 & 0.18 & 2.21 & OLS \\
\hline \multirow[t]{2}{*}{ UK } & -0.003 & $0.37 * * *$ & -0.008 & 0.5 & 2.15 & AR (2) \\
\hline & & & $\begin{array}{l}\text { Regulation of } \\
\text { dismissal } \\
\text { (variables } 16 \text { to } \\
\text { 24) }\end{array}$ & & & \\
\hline France & -0.01 & $0.35^{* * *}$ & 0.002 & 0.64 & 1.89 & AR (1) \\
\hline Germany $^{1}$ & -0.05 & $1.28 * * *$ & 0.07 & 0.17 & 2.2 & OLS \\
\hline UK & -0.02 & $0.4^{* * *}$ & 0.03 & 0.51 & 2.15 & AR (2) \\
\hline \multirow[t]{2}{*}{ USA } & $0.02 * * *$ & 0.09 & $-0.05 * * *$ & 0.51 & 2.06 & AR (1) \\
\hline & & & $\begin{array}{l}\text { Employee } \\
\text { representation } \\
\text { (variables } 25 \text { to } \\
31 \text { ) }\end{array}$ & & & \\
\hline France & $-0.02 *$ & $0.35^{* * *}$ & 0.02 & 0.66 & 1.81 & AR (1) \\
\hline Germany $^{1}$ & -0.36 & $1.23^{* * * *}$ & 0.5 & 0.18 & 2.26 & OLS \\
\hline \multirow[t]{2}{*}{ UK } & -0.001 & $0.36^{* * *}$ & -0.01 & 0.5 & 2.16 & AR (2) \\
\hline & & & $\begin{array}{l}\text { Industrial action } \\
\text { (variables } 32 \text { to } \\
40 \text { ) }\end{array}$ & & & \\
\hline France & -0.14 & $0.35^{* * *}$ & 0.16 & 0.65 & 1.81 & AR (1) \\
\hline Germany $^{1}$ & 0.12 & $1.24 * * *$ & -0.33 & 0.2 & 2.26 & OLS \\
\hline UK & 0.0001 & $0.36 * * *$ & -0.01 & 0.5 & 2.16 & AR (2) \\
\hline \multicolumn{7}{|c|}{$\begin{array}{l}\text { (B) Growth of } \\
\text { Labour } \\
\text { Productivity } \\
\text { (LBPRD) }\end{array}$} \\
\hline & & & $\begin{array}{l}A L L \\
\text { (1 to 40) }\end{array}$ & & & \\
\hline France $^{2}$ & 0.42 & $78.27 * * *$ & 3.27 & 0.35 & 2.08 & OLS \\
\hline Germany $^{1}$ & -26.54 & 58.32 & 50.08 & 0.11 & 1.52 & OLS \\
\hline UK & 2.67 & $102.82^{* * *}$ & 14.49 & 0.3 & 1.77 & $\mathrm{AR}(1)$ \\
\hline \multirow[t]{2}{*}{$\mathrm{USA}^{2}$} & -4.98 & $56.62 * *$ & $48.47 *$ & 0.17 & 1.56 & OLS \\
\hline & & & $\begin{array}{l}\text { Alternative } \\
\text { employment } \\
\text { contracts } \\
\text { (variables } 1 \text { to 8) }\end{array}$ & & & \\
\hline France $^{2}$ & 1.26 & $75.29 * * *$ & 0.99 & 0.34 & 2.09 & OLS \\
\hline Germany $^{1}$ & -0.26 & 47.66* & 2.95 & 0.05 & 1.48 & OLS \\
\hline
\end{tabular}




\begin{tabular}{|c|c|c|c|c|c|c|}
\hline UK & 2.23 & $103.34 * *$ & -3.57 & 0.31 & 1.76 & AR(1) \\
\hline & & & $\begin{array}{l}\text { Regulation of } \\
\text { working time } \\
\text { (variables } 9 \text { to } \\
\text { 15) }\end{array}$ & & & \\
\hline France $^{2}$ & -7.17 & $75.07 * * *$ & 13.13 & 0.35 & 2.07 & OLS \\
\hline Germany & $-23.65 * *$ & $62.41 * *$ & $43.84 * * *$ & 0.17 & 1.64 & OLS \\
\hline \multirow[t]{2}{*}{ UK } & 1.54 & 104.06** & 1.59 & 0.29 & 1.76 & AR (1) \\
\hline & & & 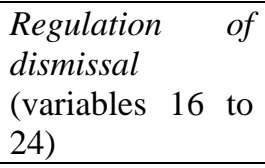 & & & \\
\hline France $^{2}$ & 0.56 & $77.39 * * *$ & 1.95 & 0.34 & 2.01 & OLS \\
\hline Germany $^{1}$ & $-8.64 * *$ & $59.9 * *$ & $23.1 * *$ & 0.18 & 1.63 & OLS \\
\hline UK & 1.48 & $103.12 * * *$ & 0.38 & 0.29 & 1.75 & AR (1) \\
\hline \multirow[t]{2}{*}{$\mathrm{USA}^{2}$} & 0.39 & $56.62 * *$ & $10.74 *$ & 0.17 & 1.56 & OLS \\
\hline & & & $\begin{array}{l}\text { Employee } \\
\text { representation } \\
\text { (variables } 25 \text { to } \\
31 \text { ) }\end{array}$ & & & \\
\hline France $^{2}$ & 0.93 & $74.41 * * *$ & 2.06 & 0.34 & 2.07 & OLS \\
\hline Germany $^{1}$ & 18.44 & $47.14^{*}$ & 24.22 & 0.06 & 1.55 & OLS \\
\hline \multirow[t]{2}{*}{ UK } & 1.56 & $103.21 * * *$ & -0.82 & 0.29 & 1.76 & AR (1) \\
\hline & & & $\begin{array}{l}\text { Industrial action } \\
\text { (variables } 32 \text { to } \\
40 \text { ) }\end{array}$ & & & \\
\hline France $^{2}$ & -8.77 & $73.22 * * *$ & 13.13 & 0.33 & 2.06 & OLS \\
\hline Germany & 10.33 & $47.29 *$ & 19.77 & 0.08 & 1.56 & OLS \\
\hline UK & 0.66 & $103.59 * *$ & 1.79 & 0.29 & 1.75 & $\operatorname{AR}(1)$ \\
\hline \multicolumn{7}{|c|}{$\begin{array}{l}\text { (C)Wage } \\
\text { Share(WGSH) }\end{array}$} \\
\hline & & & $\begin{array}{l}A L L \\
\text { (1 to 40) }\end{array}$ & & & \\
\hline France & $0.7^{* * *}$ & $-0.21 * * *$ & 0.04 & 0.97 & 1.93 & AR (2) \\
\hline Germany $^{1}$ & $0.68^{* * *}$ & $-0.2^{* * *}$ & 0.05 & 0.94 & 1.75 & AR (2) \\
\hline UK & $0.69 * * *$ & $-0.24 * * *$ & -0.01 & 0.64 & 1.95 & AR (2) \\
\hline \multirow[t]{2}{*}{$\mathrm{USA}^{2}$} & $0.7^{* * *}$ & $-0.14 * * *$ & -0.19 & 0.65 & 1.73 & AR (1) \\
\hline & & & $\begin{array}{l}\text { Alternative } \\
\text { employment } \\
\text { contracts } \\
\text { (variables } 1 \text { to 8) }\end{array}$ & & & \\
\hline France & $0.72 * * *$ & $-0.21 * * *$ & 0.01 & 0.97 & 1.9 & AR (2) \\
\hline Germany $^{1}$ & $0.73^{* * *}$ & $-0.2 * * *$ & -0.03 & 0.94 & 1.76 & AR (2) \\
\hline \multirow[t]{2}{*}{ UK } & $0.69 * * *$ & $-0.24 * * *$ & -0.004 & 0.64 & 1.96 & AR (2) \\
\hline & & & Regulation of & & & \\
\hline
\end{tabular}




\begin{tabular}{|c|c|c|c|c|c|c|}
\hline & & & $\begin{array}{l}\text { working time } \\
\text { (variables } 9 \text { to } \\
15 \text { ) }\end{array}$ & & & \\
\hline France & $0.75^{* * *}$ & $-0.2 * * *$ & -0.02 & 0.97 & 1.87 & AR (2) \\
\hline Germany $^{1}$ & $0.68^{* * *}$ & $-0.19 * * *$ & 0.04 & 0.94 & 1.76 & AR (2) \\
\hline \multirow[t]{2}{*}{ UK } & $0.69^{* * *}$ & $-0.25 * * *$ & 0.01 & 0.64 & 1.97 & AR (2) \\
\hline & & & $\begin{array}{l}\begin{array}{l}\text { Regulation } \\
\text { dismissal } \\
\text { (variables } 16 \text { to } \\
\text { 24) }\end{array} \\
\end{array}$ & & & \\
\hline France & $0.71^{* *}$ & $-0.19 * * *$ & 0.02 & 0.97 & 1.94 & AR (2) \\
\hline Germany $^{1}$ & $0.73^{* * *}$ & $-0.19 * * *$ & -0.05 & 0.94 & 1.74 & AR (2) \\
\hline UK & $0.69^{* * *}$ & $-0.24 * * *$ & -0.01 & 0.64 & 1.96 & AR (2) \\
\hline \multirow[t]{2}{*}{$\mathrm{USA}^{2}$} & $0.69^{* * *}$ & $-0.14^{* * *}$ & -0.04 & 0.65 & 1.73 & AR (1) \\
\hline & & & $\begin{array}{l}\text { Employee } \\
\text { representation } \\
\text { (variables } 25 \text { to } \\
31 \text { ) }\end{array}$ & & & \\
\hline France & $0.73^{* * *}$ & $-0.2 * * *$ & -0.004 & 0.97 & 1.87 & AR (2) \\
\hline Germany $^{1}$ & $0.57 * * *$ & $-0.23 * * *$ & 0.19 & 0.94 & 1.72 & AR (2) \\
\hline \multirow[t]{2}{*}{ UK } & $0.69 * * *$ & $-0.24 * * *$ & -0.01 & 0.64 & 1.94 & AR (2) \\
\hline & & & $\begin{array}{l}\text { Industrial action } \\
\text { (variables } 32 \text { to } \\
40 \text { ) }\end{array}$ & & & \\
\hline France & $0.64 * * *$ & $-0.21 * * *$ & 0.11 & 0.97 & 1.88 & AR (2) \\
\hline Germany $^{1}$ & $0.62 * * *$ & $-0.21 * * *$ & 0.21 & 0.94 & 1.73 & AR (2) \\
\hline UK & $0.69^{* * *}$ & $-0.24 * * *$ & 0.003 & 0.64 & 1.96 & AR (2) \\
\hline
\end{tabular}

*** Significant at the 1 per cent level.

** $\quad$ Significant at the 5 per cent level.

* $\quad$ Significant at the 10 per cent level.

$\checkmark \quad$ The fitted equation is

$$
\mathrm{Y}=\mathrm{a}+\mathrm{b} . \text { DLRGDP + c.LR }
$$

where $\mathrm{Y}$ is the dependent variable, the growth rate of civil employment, DLN or the growth of labour productivity (LBPRD) or the wage share in total economy (WGSH), DLRGDP is the growth rate of real GDP (RGDP), LR is the labour regulation index (aggregate or its different components taken one at a time), a, b and c are regression parameters. This equation is fitted on the ordinary least squares (OLS) basis and a twelve order Lagrange Multiplier Test is conducted to ascertain the order of autocorrelation of the residuals. To tackle the problem of autocorrelation (if any), the Exact Newton-Raphson Iterative Method was used to estimate the parameters. The choice between AR (1) and AR (2) is done on the basis of the log-likelihood ratio tests of $\mathrm{AR}(1)$ versus OLS and $\mathrm{AR}(2)$ versus $\mathrm{AR}(1)$.

Notes: 
1 The period of study starts from 1972 (due to lack of data).

2 The period of study ends at 2005 (due to lack of data).

Sources: CBR Labour Regulation Dataset (Deakin, Lele and Siems, 2007; http://www.cbr.cam.ac.uk/research/programme2/project2-20.htm); OECD (OECD's iLibrary); International Monetary Fund, International Financial Statistics 2008.

Data on civil employment are available from the OECD (the OECD iLibrary) and data on real GDP are available from the IMF (International Financial Statistics). To avoid the problem of non-stationarity ${ }^{5}$ we take the first log-difference of the two series; these give us the annual growth rates of employment and real output (respectively) over the period 1971-2006. We then fit the following regression, with a time trend:

$$
\mathrm{DLN}=\mathrm{a}+\mathrm{b} \cdot \mathrm{DLRDGP}+\mathrm{c} \cdot \mathrm{LR}
$$

DLN is the growth rate of employment, DLRDGP is the growth rate of real GDP (RGDP), LR is labour regulation index (aggregate or its different components taken one at a time), and a, b and c are regression parameters.

Our analysis shows, as we would expect, that the growth rates of real output and employment are positively related in all the countries. The aggregate labour regulation index, however, has no significant relationship (positive or negative) with employment growth in France, Germany ${ }^{6}$ and the UK, after controlling for the macroeconomic environment as represented by the trend in the growth of real GDP. This is also true for the different components of the labour regulation index. There is one exception - the trend in French labour law on working time is positively

5 Macroeconomic series are often found to be non-stationary at various levels, with or without time-trends (Nelson and Plosser, 1992). If due adjustments (first or higher order differencing) are not made to make these series stationary, the problem of spurious regressions may arise. The first (log)-differencing of the macroeconomic series carried out here makes them stationary (details of these technicalities are omitted for the sake of brevity).

6 German employment growth shows one outlier in 1991. We used a spike dummy (=1 for 1991 and 0 otherwise) and re-ran the regression. Our findings were unaffected. 
related to employment growth. The USA is the only country where we find an inverse relationship between labour regulation and employment growth. This is because of the changes in the regulation of dismissal (the aggregate of variables 16 to 24) - the only area in which there was a significant change in US law over the period. ${ }^{7}$ This refers to the introduction of the federal WARN law of 1988 (and effective from 1989) mandating minimum notice periods and severance pay in the event of economic dismissals. ${ }^{8}$

Next we examine whether labour law changes have an impact on labour productivity. We have data on annual growth rate of labour productivity per unit of labour input (LBPRD) for the four countries for the period 1971-2005/2006. Replicating our regression analysis by replacing DLN by LBPRD in Equation 1, we can observe that the growth of real output and labour productivity growth are directly related. There is, however, no significant relationship between the productivity growth rate and trends in the labour regulation indices for the two of the four countries, France and UK (irrespective of the inclusion of the real growth rate in the regression). For Germany, the indices concerning working time and dismissal are

7 These findings hold good even if we do not adjust for macroeconomic fluctuations by setting $b=0$ (that is, ignoring the real GDP growth rate) in the regression equation. Our findings on labour law and employment growth are also robust to this revised regression analysis, with one exception: the positive relationship between employment growth and working time regulation in France cannot be maintained when this revised regression is fitted.

8 The employment growth rate in the USA fell sharply between 1989 and 1991, at a point when the growth rate of GDP was also falling and there was a (short) recession. We observe the inverse relationship referred to in the text after controlling for the rate of growth of GDP. After 1992 US employment growth resumed but for the most of the 1990s the rate of growth was lower than it was in the 1970s and 1980s. It is unlikely, in principle, that this long-run trend can be ascribed solely to the WARN law, given the relatively limited nature of that legislation and the high possibility that it simply crystallised a pre-existing practice of voluntary notice and severance (see Addison and Blackburn, 1994). As we suggest in the text below (section 3.4), in the context of a long time series such as this, very great caution should be exercised in extrapolating from a single legal reform. However, the result is at least suggestive, and highlights the potential importance of this question, which could be explored more deeply in future research by the addition of further controls and by sector-specific analyses. 
positively correlated with labour productivity growth at a very high level of statistical significance (provided we take into account the real growth rate). On the whole, there is somewhat weak evidence (significant at the 10 per cent level) of a positive relationship between the US labour regulation index and labour productivity growth which is associated with the change in the regulation of dismissal brought about by the WARN law after 1989.

Next we examine whether labour regulations affect income distribution. We use the share of wages in the total economy, for which time series exist for the period and countries in question, as a proxy for the redistributive effect of labour law. The wage share showed a declining trend in all the countries throughout the period; in France and Germany there were rising trends in the 1970s and declining trends thereafter while the UK experienced a mild declining trend amid cyclical fluctuations. In Equation 1 we replace DLN by a wage share variable (WGSH). In all the four countries the wage share and real growth rate are inversely related the higher the real growth rate, the lower is the wage share. However, there is no significant relationship between labour regulation and the wage share. ${ }^{9}$ Thus labour law changes (which have mainly had the effect of strengthening of protection for workers, with the exception of the British case from the early 1980s to the mid-1990s) cannot be held responsible for labour's declining share of national income over this period in each of the countries in our sample.

Finally we look at the issue of complementarities across forms of regulation. We can see from the correlation matrix set out in Table 3 that the level of labour regulation is positively correlated with that of shareholder and creditor protection in both France and Germany. The same is true, but to a lesser extent, in the United States. In other words, in these systems, there are complementarities between the prevailing modes of regulation of labour relations and corporate governance. In France and Germany, for example, a high level of protection for workers has not proved incompatible with greater shareholder protection: the score for shareholder rights has been rising in these two countries across the whole

9 This result holds good even if we ignore the real growth rate in the regression equation. 
period (Lele and Siems, 2007). In the UK, the situation is reversed: there is an negative relationship between the level of labour law regulation and the protection accorded to shareholders and creditors, (although it is not statistically significant). In the US case, there is a weak but significant correlation between the trends in regulation across the three areas of law. This is a finding which requires some explanation, in the sense that it perhaps surprising that the inverse relationship between labour law and company law that we find for the UK is not replicated for the US. The explanation lies in the relatively low score given to US shareholder protection law. For reasons explored in more detail elsewhere (see Lele and Siems, 2007), US law is less protective of shareholder rights than is conventionally believed; however, dispersed ownership and a high degree of liquidity in capital markets might well be explained by factors not accounted for in the shareholder protection index, in particular the intensive nature of securities market regulation in the US context and the substantial resources devoted to enforcement through the Securities and Exchange Commission (see Jackson and Roe, 2007). On this basis, a more complete picture of the regulatory framework in the US would probably be consistent with the view that there is an inverse relationship between labour law and shareholder protection, as in the UK.

Table 3

Correlations between labour regulation, shareholder protection and creditor rights indices, 1970-2005

\section{France}

\begin{tabular}{|l|l|l|l|}
\hline & $\begin{array}{l}\text { Labour Regulation } \\
\text { Index }\end{array}$ & $\begin{array}{l}\text { Shareholder } \\
\text { Protection } \\
\text { Index }\end{array}$ & $\begin{array}{l}\text { Creditor Rights } \\
\text { Index }\end{array}$ \\
\hline $\begin{array}{l}\text { Labour Regulation } \\
\text { Index }\end{array}$ & 1.0 & & \\
\hline $\begin{array}{l}\text { Shareholder } \\
\text { Protection } \\
\text { Index }\end{array}$ & $0.74^{*}$ & 1.0 & 1.0 \\
\hline $\begin{array}{l}\text { Creditor Rights } \\
\text { Index }\end{array}$ & $0.82^{*}$ & $0.88^{*}$ & \\
\hline
\end{tabular}

\section{Germany}




\begin{tabular}{|l|l|l|l|}
\hline & $\begin{array}{l}\text { Labour Regulation } \\
\text { Index }\end{array}$ & $\begin{array}{l}\text { Shareholder Protection } \\
\text { Index }\end{array}$ & $\begin{array}{l}\text { Creditor Rights } \\
\text { Index }\end{array}$ \\
\hline $\begin{array}{l}\text { Labour Regulation } \\
\text { Index }\end{array}$ & 1.0 & & \\
\hline $\begin{array}{l}\text { Shareholder Protection } \\
\text { Index }\end{array}$ & $0.85^{*}$ & 1.0 & 1.0 \\
\hline $\begin{array}{l}\text { Creditor Rights } \\
\text { Index }\end{array}$ & $0.73^{*}$ & $0.89^{*}$ & \\
\hline
\end{tabular}

UK

\begin{tabular}{|l|l|l|l|}
\hline & $\begin{array}{l}\text { Labour Regulation } \\
\text { Index }\end{array}$ & $\begin{array}{l}\text { Shareholder Protection } \\
\text { Index }\end{array}$ & $\begin{array}{l}\text { Creditor Rights } \\
\text { Index }\end{array}$ \\
\hline $\begin{array}{l}\text { Labour Regulation } \\
\text { Index }\end{array}$ & 1.0 & & \\
\hline $\begin{array}{l}\text { Shareholder Protection } \\
\text { Index }\end{array}$ & -0.13 & 1.0 & 1.0 \\
\hline $\begin{array}{l}\text { Creditor Rights } \\
\text { Index }\end{array}$ & -0.25 & $0.88^{*}$ & \\
\hline
\end{tabular}

\section{USA}

\begin{tabular}{|l|l|l|l|}
\hline & $\begin{array}{l}\text { Labour Regulation } \\
\text { Index }\end{array}$ & $\begin{array}{l}\text { Shareholder Protection } \\
\text { Index }\end{array}$ & $\begin{array}{l}\text { Creditor Rights } \\
\text { Index }\end{array}$ \\
\hline $\begin{array}{l}\text { Labour Regulation } \\
\text { Index }\end{array}$ & 1.0 & & \\
\hline $\begin{array}{l}\text { Shareholder Protection } \\
\text { Index }\end{array}$ & $0.38^{*}$ & 1.0 & 1.0 \\
\hline $\begin{array}{l}\text { Creditor Rights } \\
\text { Index }\end{array}$ & $0.88^{*}$ & $0.4^{*}$ & \\
\hline
\end{tabular}

* Significant at the 5\% level.

Source: CBR Datasets on Labour Regulation, Shareholder Protection and Creditor Rights (Deakin, Lele and Siems, 2007; Lele and Siems, 2007; Armour, Deakin, Lele and Siems, 2008;

http://www.cbr.cam.ac.uk/research/programme2/project2-20.htm). 


\section{INTERPRETING THE EVIDENCE}

Table 4 summarises the results which have just been set out. The only negative relationship is that between dismissal regulation and employment growth in the US; but there is a countervailing increase here in labour productivity. It is difficult to draw strong conclusions either way from the US case because there were very few changes of any kind in the law during the period being reviewed. While the time-series analysis we have conducted is well suited to analyzing the consequences of change, it is less effective in contexts where the variables being studied are stable over time. The US result is driven by just one change in the law, the introduction of minimum notice and severance pay rules in the WARN legislation. Therefore it would be reasonable to regard it is as somewhat tentative. $^{10}$

Table 4

Summary of Main Findings

\begin{tabular}{|l|l|l|c|}
\hline Legal variable & $\begin{array}{l}\text { Outcome } \\
\text { variable }\end{array}$ & Country & Relationship \\
\hline $\begin{array}{l}\text { Regulation of working } \\
\text { time }\end{array}$ & $\begin{array}{l}\text { Employment } \\
\text { growth }\end{array}$ & France & + \\
\hline & Productivity & Germany & + \\
\hline $\begin{array}{l}\text { Regulation of } \\
\text { dismissal }\end{array}$ & $\begin{array}{l}\text { Employment } \\
\text { growth }\end{array}$ & United States & - \\
\hline & Productivity & United States & + \\
\hline & Productivity & Germany & + \\
\hline
\end{tabular}

${ }^{10}$ Recent work on the impact of derogations from the employment at will rule in several US states in the 1980s and 1990s suggests that the effects of changes to employment law may be highly complex in the American context: it reports a link between the tightening of legal controls over dismissal and an increase in employment growth, a rise in labour productivity, but a fall in total factor productivity in the manufacturing sector (Autor et al., 2007). 
The regulation of working time is positively correlated with productivity levels in France and Germany, and the regulation of dismissal is positively correlated with productivity levels in Germany; in neither case is there evidence of offsetting reductions in employment. These findings imply that labour regulation of this kind may have beneficial impacts when combined with other institutions in the context of coordinated market economies. The precise nature of these complementarities cannot be observed in the data we have examined here, but could be studied in future work.

The labour law indicator with the strongest relationship to the economic variables is the regulation of dismissal, which has a positive effect on productivity in two of the four countries studied. Working time regulation is also shown to have a relationship to employment growth and productivity in some contexts. Employee representation law and the regulation of the right to strike do not appear to be correlated with either employment or productivity.

We therefore have evidence that labour law change has had a positive relationship to employment growth and to increases in productivity in certain countries and in particular policy contexts. This relationship is by no means uniform across the countries in the sample, and, indeed, there are some contexts in which we find no link at all, either positive or negative, between increasing regulation and economic outcomes. This varied picture is what the indeterminacy hypothesis would predict. Because labour laws most often codify and extend existing practices, rather than imposing entirely novel rules on a previously regulated labour market, we would not necessarily expect the consequences of legal change to be substantial in every case. It is also possible that the parties to employment contracts can adjust to new legislation in ways which reduces any negative (or positive) economic consequences (Freeman, 2005). But we can also see that labour law is not trivial: we report statistically significant relationships between labour law trends and economic impacts in certain contexts. These findings offer support to the complementarity hypothesis, in so far as they suggest that some aspects of labour law regulation, in particular laws on working time and dismissal, are most likely to have the positive economic impacts predicted for them in coordinated market systems, such as France and Germany. Our results are consistent with those of Gatti (2008) on the existence of 
complementarities between employment protection legislation and ownership concentration in coordinated market systems, although we cannot observe the effects of ownership concentration directly in our dataset. Our findings qualify or at least complicate the complementarity hypothesis in one respect: if we look solely at developments in legal rules, we can see that in France and Germany, there has been a high level of labour law regulation but also an increase in shareholder protection over the period in question. It is beyond the scope of the present study to consider how far this change in the law governing shareholder rights might have led to a shift in the prevailing pattern of share ownership in these countries. This is a matter for future research. In Britain, by contrast, there is evidence of an inverse relationship between the trend in labour law and those in company and insolvency law. This is what we would expect from a comparative political economy perspective - strong shareholder protection is complementary to weak labour law. In the American case there is no such negative relationship, but nor is the degree of correlation between the different areas of regulation as strong as it is in France and

Germany. Some possible explanations for the surprising US result have been noted (see section 3.3 above).

\section{CONCLUSIONS}

This paper has offered a reassessment of the long-run economic impact of labour laws. We suggested, firstly, that a theoretical reappraisal of the role of the law in shaping economic outcomes was needed. In most economic models, labour laws are seen as an exogenous interference with market relations. We argued, drawing on recent developments in legal origins theory and in comparative political economy, that this standard approach is potentially misleading. This is, firstly, because labour laws are to, a certain degree, endogenous to the economic and political environments in which they operate. Formalised labour regulations generalize and extend pre-existing social practices which can be understood as evolved responses to coordination failures in labour markets; in addition, they are shaped to varying degrees by interest-group configurations, macroeconomic conditions, and long-run legal and political structures. To say that labour law is shaped by elements in its economic environment as well as by political and legal-institutional factors is not to imply a perfect fit; 
however, it may well be equally mistaken to assume that labour laws always impose exogenous costs on firms. Secondly, and relatedly, labour regulation is pluralistic: labour laws take effect not in isolation but through and alongside self-regulation on the part of market actors and social norms. An understanding of the economic impact of the formal law should take into account the mediating role of these other institutions. Thirdly, labour laws are systemic, that is to say, they operate in conjunction with other, complementary institutions in market economies. It is necessary to pay regard to these potential interactions when predicting the effects of a change in the law.

The implications of viewing labour law in the ways just suggested are farreaching. The effects of labour law may be more indeterminate than previously thought, in the sense of being highly context-dependent (the 'indeterminacy hypothesis'). More specifically, labour law rules may be expected to have efficiency-enhancing effects in situations where they operate in conjunction with other institutional phenomena (the 'complementarity hypothesis'). The perspective we have suggested also opens up new insights on the claim that legal infrastructure may influence both the content of labour law and its impact in terms of efficiency (the 'legal origins hypothesis').

A theoretical reappraisal of this kind points up the need for a better empirical understanding of the way legal systems operate in economic contexts such as that of the labour market. One aspect of this is the development of reliable measures of legal regulation which capture change in the content of rules over time. In this paper we have discussed methodological issues involved in the coding of labour laws and presented evidence from a new, longitudinal index of changes in labour law regulation in France, Germany, the UK and the US from the early 1970s to the present day. Analysis of the dataset offers some support for the weakform legal origin hypothesis, which claims that legal infrastructure has an effect on the content of the law. However, the strong-form legal origin claim, that common law systems are more likely to produce efficiencyenhancing rules than civil law ones, is not supported. Instead, there is evidence to suggest that the economic effects of labour laws are not just highly varied and complex, a result which is compatible with the indeterminacy hypothesis, but also that they may be efficiency-enhancing in certain contexts and in particular in civil law systems, a conclusion 
which is consistent with the complementarity hypothesis. Over the period studied, the strengthening of dismissal laws had positive effects on employment and productivity growth in France and Germany, and tighter working time laws had a positive impact on employment growth in France, after controlling for the macroeconomic environment as measured by the growth in real GDP. A slight strengthening of dismissal controls had a negative impact on employment growth but a positive effect on productivity growth in the US. While these results must, in some respects, be seen as tentative, they suggest that time-series analyses can cast new light on the empirical effects of labour laws, while also confirming the need for a more nuanced theoretical understanding of this issue. 


\section{Bibliography}

Addison, J. and Blackburn, M. (1994) 'Policy watch: the Worker Adjustment and Retraining Notification Act' Journal of Economic Perspectives, 8: 181-190.

Amable, B. (2004) The Diversity of Modern Capitalism (Oxford: OUP).

Amable, B., Demmou, L. and Gatti, D. (2007) 'Employment performance and institutions: new answers to an old question' IZA Discussion Paper No. 2731.

Amable, B., Ernst, E. and Palombarini, S. (2005) 'How do financial markets affect industrial relations? An institutional complementarity approach’ Socio-Economic Review, 3; 311-330.

Ahlering, B. and Deakin, S. (2007), 'Labour regulation, corporate governance and legal origin: a case of institutional complementarity?' Law \& Society Review, 41: 865-908.

Aoki, M. (2001) Towards a Comparative Institutional Analysis (Cambridge, MA: MIT Press).

Armour, J., Deakin, S., Sarkar, P., Siems, M. and Singh, A. (2007) 'Shareholder protection and stock market development: an empirical test of the legal origins hypothesis', CBR Working Paper No. 358: http://www.cbr.cam.ac.uk.

Armour, J., Deakin, S., Lele, P. and Siems, M. (2008) 'How legal norms evolve: new evidence from panel data' forthcoming, CBR Working Paper series: http://www.cbr.cam.ac.uk.

Autor, D., Kerr, W. and Kugler, A. (2007) 'Do employment protections reduce productivity? Evidence from US states’, IZA Discussion Paper No. 2571.

Baker, D., Glyn, A., Howell, D. and Schmitt, J. (2005) 'Labour market institutions and unemployment: a critical assessment of cross-country 
evidence', in D. Howell (ed.) Fighting Unemployment: The Limits of Free Market Orthodoxy (Oxford: OUP).

Bassanini, A. and Duval, R. (2006) 'Employment patterns in OECD countries: reassessing the role of policies and institutions', OECD Social, Employment and Migration Working Paper No. 35.

Bassanini, A. and Venn, D. (2007) 'Assessing the impact of labour market policies on productivity: a difference-in-differences approach'. OECD Social, Employment and Migration Paper No. 54.

Barker, R. and Rueda, D. (2007) 'The political determinants of corporate governance reform', presented to the conference on Changing Institutions (in Developed Democracies): Economics, Politics and Welfare, Paris, May 2006.

Beck T., Demirgüc-Kunt A. and Levine R. (2003a) 'Law and finance: why does legal origin matter?' Journal of Comparative Economics, 31: 653675.

Berg, J. and Cazes, S. (2007) 'The Doing Business indicators: measurement issues and political implications', Economic and Labour Market Paper 2007/6, ILO.

Bertola, G. (2007) 'Labour market regulation: motives, measures, effects', report produced in the framework of the ILO project on 'The Economic Impact of Labour Standards', available on: http://www.personalweb.unito.it/giuseppe.bertola/\#downloads $\quad$ (last consulted June 2008).

Boeri, T., Nicoletti, G. and Scarpetta, S. (2000) 'Regulation and labour market performance’ NBER Discussion Paper 2420.

Botero J., Djankov S., La Porta R., Lopez-de-Silanes F. and Shleifer A. (2004) 'The regulation of labour' Quarterly Journal of Economics, 119: 1340-1382.

Card, D. and Krueger, A. (1997) Myth and Measurement (Princeton, NJ: Princeton University Press). 
Carvalho, F. and Deakin, S. (2008) 'System and evolution in corporate governance' forthcoming, CBR Working Paper series: http://www.cbr.cam.ac.uk.

Checchi, D. and Nunziata, L. (2007) 'Are labour market institutions endogenous? An investigation of unemployment, unions and wages', presented to the conference on Changing Institutions (in Developed Democracies): Economics, Politics and Welfare, Paris, May 2006; mimeo: http://checchi.economia.unimi.it/.

Chor, D. and Freeman, R. (2005), 'The 2004 Global Labour Survey: Workplace institutions and practices around the world', NBER Working Paper No 11598.

Deakin, S. (2003) 'Evolution for our time: a theory of legal memetics' Current Legal Problems, 55: 1-42.

Deakin, S., Lele, P., Siems, M. (2007), 'The evolution of labour law: calibrating and comparing regulatory regimes' International Labour Review, 146: 133-162.

Deakin, S. and Wilkinson, F. (2005) The Law of the Labour Market: Industrialization, Employment, and Legal Evolution (Oxford: OUP).

Feldmann, H. (2008) 'The quality of industrial relations and unemployment around the world' Economics Letters, 99: 200-3.

Freeman, R. (2005) 'Labour market institutions without blinders: the debate over flexibility and labour market performance' NBER Working Paper No. 11286.

Galanter, M. (1974) 'Why the "haves" come out ahead: speculations on the limits of legal change' Law \& Society Review, 9: 95-160.

Gatti, D. (2008) 'Macroeconomic effects of ownership structure in OECD countries’ IZA Discussion Paper No. 3415. 
Glaeser E. and Shleifer A. (2002) 'Legal origins' Quarterly Journal of Economics, 117:1193-1229.

Gourevitch, P. and Shinn, J. (2005) Political Power and Corporate Control: The New Global Politics of Corporate Governance (Princeton, NJ: Princeton University Press).

Grubb, D. and W. Wells (1993) 'Employment regulation and patterns of work in EC countries’ OECD Economic Studies, 21: 7-58.

Hyde, A. (2006) 'What is labour law?', in G. Davidov and B. Langille (eds.) Boundaries and Frontiers of Labour Law, 37-61(Oxford: Hart Publishing).

IMF (2003) 'Unemployment and labour market institutions: why reforms pay off', in IMF (ed.) World Economic Outlook, ch. 4 (Washington, DC: International Monetary Fund).

Iversen, T. and Soskice, D. (2007) 'Distribution and redistribution: the shadow of the nineteenth century' presented to the conference on Changing Institutions (in Developed Democracies): Economics, Politics and Welfare, Paris, May 2006; forthcoming, Socio-Economic Review.

Jackson, H. and Roe, M. (2007) 'Public enforcement of securities laws: preliminary evidence', paper presented to the Second Annual Conference on Empirical Legal Studies, NYU, November 2007; available at http://ssrn.com/abstract=1000086.

Koeniger, W. (2005) ‘Dismissal costs and innovation’ Economics Letters, 88: 79-85.

Koeniger, W. and Vindigni, A. (2003) 'Employment protection and product market regulation’ IZA Discussion Paper No. 880.

La Porta R., Lopez-de-Silanes, F. and Shleifer, A. (2008) 'The economic consequences of legal origins' Journal of Economic Literature, 46: 285332. 
Lee, S. and McCann, D. (2007) 'Measuring labour market institutions: conceptual and methodological questions on "working time rigidity"', in J. Berg and D. Kucera (eds.) In Defence of Labour Market Institutions: Cultivating Justice in the Developing World (London: Palgrave Macmillan).

Legrand, P. (1999) Fragments on Law-as-Culture (Deventer: Willink).

Lele, P. and Siems. M. (2007), 'Shareholder protection: a leximetric approach’ Journal of Corporate Law Studies, 7: 17-50.

Luhmann, N. (2006) Law as a Social System. Transl. K. Ziegert, ed. F. Kastner, R. Nobles, D. Schiff and R. Ziegert (Oxford: OUP).

Manning, A. (2005) Monopsony in Action: Imperfect Competition in Labour Markets (Princeton, NJ: Princeton University Press).

Nelson, C. and Plosser, C. (1982) 'Trends and random walks in macreconomic time series: some evidence and implications' Journal of Monetary Economics, 10: 139-162.

Nicoletti, G. and Scarpetta, S. (2003) 'Regulation, productivity and growth: OECD evidence’ Economic Policy, 18: 9-72.

OECD (1994) OECD Jobs Study, Evidence and Explanations, Part I: Labour Market Trends and Underlying Forces of Change (Paris: Organization for Economic Cooperation and Development).

OECD (2004) Employment Outlook (Paris: Organization for Economic Cooperation and Development).

Pagano, M. and Volpin, P. (2005) 'The political economy of corporate governance’ American Economic Review, 95: 1005-30.

Pozen, D. (2006) 'The regulation of labor and the relevance of legal origin’ Comparative Labor Law and Policy Journal, 28: 43-56. 
Rajan, R. and Zingales, L. (2003). 'The great reversals: the politics of financial development in the twentieth century' Journal of Financial Economics 69: 5-50.

Rodrik, D. (2005) 'Why we learn nothing from regressing economic growth on policies', working paper, Harvard University: http://ksghome.harvard.edu/ drodrik/policy\%20regressions.pdf.

Rogowski, R. and Wilthagen, T. (1994) 'Reflexive labour law: an introduction', in R. Rogowski and T. Wilthagen (eds.) Reflexive Labour Law (Deventer: Kluwer)

Rubery, J. and Edwards, P. (2003) 'Low pay and the National Minimum Wage', in P. Edwards, (ed.) Industrial Relations: Theory and Practice $2^{\text {nd }}$. edition (Oxford: Blackwell).

Saint-Paul, G. (1997) 'Is labour rigidity harming Europe's competitiveness? The effect of job protection on the pattern of trade and welfare’ European Economic Review, 41: 499-506.

Siems, M. (2007) 'Reconciling law \& finance and comparative law' McGill Law Journal, 52: 55-81.

Spamann, H. (2006), 'On the insignificance and/or endogeneity of La Porta et al.'s "Anti-director rights index" under consistent coding', ECGI Law Working Paper No 67/2006.

Teubner, G. (1993) Law as an Autopoietic System (Oxford: Blackwell).

Teubner, G. (2001), 'Legal irritants: how unifying law ends up in new divergences' in P. Hall and D. Soskice (eds.) Varieties of Capitalism 41742 (Oxford: OUP).

Verkerke, J. (2008) 'The law and economics of discharge' University of Virginia Law School, John M. Olin Program in Law and Economics Working Paper No. 50. 
Warneryd, K. (1998) 'Conventions and transaction costs', in P. Newman (ed.) The New Palgrave Dictionary of Economics and the Law, Vol. I (London: Macmillan).

World Bank (2008) Doing Business 2008: Comparing Regulation in 178 Economies (Washington, DC: International Bank for Reconstruction and Development).

Zweigert, K. and Kötz, H. (1998) An Introduction to Comparative Law trans. T. Weir (Oxford: OUP). 
Appendix: Excerpt from CBR Labour Regulation Dataset: Coding of Dismissal Law in the UK 


\begin{tabular}{|c|c|c|c|}
\hline C. Regulation of dismissal & & & \\
\hline $\begin{array}{l}\text { 16. Legally mandated notice period (all } \\
\text { dismissals) }\end{array}$ & $\begin{array}{l}\text { Measures the length of notice, in } \\
\text { weeks, that has to be given to a worker } \\
\text { with } 3 \text { years' employment. Normalise } \\
\text { the score so that } 0 \text { weeks = } 0 \text { and } 12 \\
\text { weeks = } 1 \text {. }\end{array}$ & $\begin{array}{l}\text { 1970-1976: } \\
0.19 \\
1977-: 0.25\end{array}$ & $\begin{array}{l}\text { A 2-week norm was in effect between } 1970 \text { and } 1975 \\
\text { (Contracts of Employment Act 1963); from } 1975 \\
\text { (Employment Protection Act 1975) the period was } 3 \\
\text { weeks. }\end{array}$ \\
\hline $\begin{array}{l}\text { 17. Legally mandated redundancy } \\
\text { compensation }\end{array}$ & $\begin{array}{l}\text { Measures the amount of redundancy } \\
\text { compensation payable to a worker } \\
\text { made redundant after } 3 \text { years of } \\
\text { employment, measured in weeks of } \\
\text { pay. Normalise the score so that } 0 \\
\text { weeks }=0 \text { and } 12 \text { weeks }=1 \text {. }\end{array}$ & 1970-: 0.25 & $\begin{array}{l}\text { The normal rule throughout this period (Redundancy } \\
\text { Payments Act } 1965 \text { and successor statutes) is that } \\
\text { redundancy payments were calculated on the basis of } 1 \\
\text { week's employment for each year worked between the } \\
\text { ages of } 22 \text { and } 41 \text { ( } 1.5 \text { week for years over age of } 41 \text {, and } \\
0.5 \text { weeks for years worked between } 18 \text { and 22). This is } \\
\text { subject to a statutory ceiling. }\end{array}$ \\
\hline $\begin{array}{l}\text { 18. Minimum qualifying period of } \\
\text { service for normal case of unjust } \\
\text { dismissal }\end{array}$ & $\begin{array}{l}\text { Measures the period of service } \\
\text { required before a worker qualifies for } \\
\text { general protection against unjust } \\
\text { dismissal. Normalise the score so that }\end{array}$ & $\begin{array}{l}\text { 1970-1971: } 0 \\
\text { 1972-1973: } \\
0.33\end{array}$ & $\begin{array}{l}\text { The qualifying period for general unfair dismissal } \\
\text { protection was two years between } 1972 \text { and } 1974 \\
\text { (Industrial Relations Act 1971); one year from } 1974 \text { to } \\
1975 \text { (Trade Union and Labour Relations Act 1974); six }\end{array}$ \\
\hline
\end{tabular}




\begin{tabular}{|c|c|c|c|}
\hline & 3 years or more $=0,0$ months $=1$ & 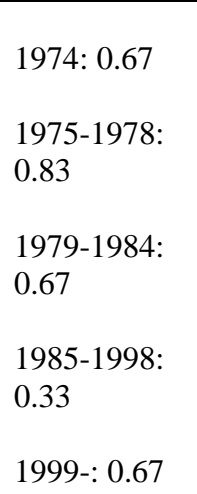 & $\begin{array}{l}\text { months between } 1975 \text { and } 1979 \text { (Employment Protection } \\
\text { Act 1975); one year between } 1979 \text { and } 1985 \text { ('July } \\
\text { orders', 1979); two years between } 1985 \text { and } 1999 \text { (SI } \\
\text { 1985); and one year again from } 1999 \text { (Employment } \\
\text { Relations Act 1999). }\end{array}$ \\
\hline $\begin{array}{lll}\text { 19. Law imposes } & \text { procedural } \\
\text { constraints on dismissal } & \end{array}$ & $\begin{array}{l}\text { Equals } 1 \text { if a dismissal is necessarily } \\
\text { unjust if the employer fails to follow } \\
\text { procedural requirements prior to } \\
\text { dismissal }\end{array}$ & $\begin{array}{l}\text { 1970-1971: } 0 \\
\text { 1972-1986: } \\
0.33\end{array}$ & $\begin{array}{l}\text { The general rule of UK unfair dismissal law is that a } \\
\text { dismissal is likely to be unfair if the employer fails to } \\
\text { adhere to procedural standards but is not inevitably so. } \\
\text { Up to } 1987 \text { the employer could avoid a finding of unfair } \\
\text { dismissal by showing that the lack of due process would }\end{array}$ \\
\hline
\end{tabular}




\begin{tabular}{|c|c|c|c|}
\hline & $\begin{array}{l}\text { Equals } 0.67 \text { if failure to follow } \\
\text { procedural requirements will normally } \\
\text { lead to a finding of unjust dismissal. } \\
\text { Equals } 0.33 \text { if failure to follow } \\
\text { procedural requirement is just one } \\
\text { factor taken into account in unjust } \\
\text { dismissal cases. } \\
\text { Equals } 0 \text { if there are no procedural } \\
\text { requirements for dismissal. } \\
\text { Scope for gradations between } 0 \text { and } 1 \\
\text { to reflect changes in the strength of the } \\
\text { law. }\end{array}$ & $\begin{array}{l}\text { 1987-2004: } \\
0.67 \\
\text { 2004-: } 0.33\end{array}$ & $\begin{array}{l}\text { have made no difference to the outcome because the } \\
\text { dismissal was substantively fair. In } 1987 \text { that rule was } \\
\text { reversed by decision of the House of Lords (Polkey v. } \\
\text { A.E. Dayton Services Ltd.). With effect from } 2004 \text { the } \\
\text { Polkey decision was reversed by statute (Employment } \\
\text { Act 2002) but only if the employer could show that it had } \\
\text { complied with a minimal obligation to hold a hearing } \\
\text { prior to dismissal. This latter requirement is substantially } \\
\text { below the threshold of procedural fairness which } \\
\text { generally applies to unfair dismissal law. }\end{array}$ \\
\hline $\begin{array}{lcr}20 . & \text { Law imposes } & \text { substantive } \\
\text { constraints on dismissal } & \end{array}$ & $\begin{array}{l}\text { Equals } 1 \text { if dismissal is only } \\
\text { permissible for serious misconduct or } \\
\text { fault of the employee. }\end{array}$ & $\begin{array}{l}\text { 1970-1971: } 0 \\
\text { 1972-: } 0.5\end{array}$ & $\begin{array}{l}\text { UK unfair dismissal law (now contained in Employment } \\
\text { Rights Act 1996) sets out a range of 'potentially fair' } \\
\text { reasons for dismissal which include lack of capability, }\end{array}$ \\
\hline
\end{tabular}




\begin{tabular}{|l|l|l|l|}
\hline & $\begin{array}{l}\text { Equals 0.67 if dismissal is lawful } \\
\text { according to a wider range of } \\
\text { legitimate reasons (misconduct, lack of } \\
\text { capability, redundancy, etc.). }\end{array}$ \\
$\begin{array}{l}\text { Equals } 0.33 \text { if dismissal is permissible } \\
\text { if it is 'just' or 'fair' as defined by case } \\
\text { law. }\end{array}$ & $\begin{array}{l}\text { misconduct, lack of qualifications, redundancy, statutory } \\
\text { bar, and a residual category (some other substantial } \\
\text { reason of a kind to justify the dismissal). The existence } \\
\text { of the residual category is important in diluting the } \\
\text { protection of employees, suggesting a coding between the } \\
\text { middle two categories set out in the template. } \\
\text { no cause dismissal is normally } \\
\text { permissible). }\end{array}$ \\
$\begin{array}{l}\text { Scope for gradations between 0 and } 1 \\
\text { to reflect changes in the strength of the } \\
\text { law. }\end{array}$ & \\
\hline
\end{tabular}




\begin{tabular}{|c|c|c|c|}
\hline $\begin{array}{l}\text { 21. Reinstatement normal remedy for } \\
\text { unfair dismissal }\end{array}$ & $\begin{array}{l}\text { Equals } 1 \text { if reinstatement is the normal } \\
\text { remedy for unjust dismissal and is } \\
\text { regularly enforced. } \\
\text { Equals } 0.67 \text { if reinstatement and } \\
\text { compensation are, de iure and de facto, } \\
\text { alternative remedies. } \\
\text { Equals } 0.33 \text { if compensation is the } \\
\text { normal remedy. } \\
\text { Equals } 0 \text { if no remedy is available as of } \\
\text { right. } \\
\text { Scope for further gradations between } 0 \\
\text { and } 1 \text { to reflect changes in the strength } \\
\text { of the law. }\end{array}$ & $\begin{array}{l}\text { 1970-1971: } 0 \\
\text { 1972-: } 0.33\end{array}$ & $\begin{array}{l}\text { Reinstatement is stated to be the 'principal' remedy for } \\
\text { unfair dismissal (Employment Rights Act 1996) but this } \\
\text { rule is qualified by many significant restrictions on the } \\
\text { powers of tribunals to award reinstatement. In practice } \\
\text { reinstatement is very rarely awarded. There are also only } \\
\text { very limited powers to order the interim reinstatement of } \\
\text { an applicant pending the full hearing of the claim. }\end{array}$ \\
\hline 22. Notification of dismissal & Equals 1 if by law or binding collective & 1970-1971: 0 & The normal rule since the inception of the unfair \\
\hline
\end{tabular}




\begin{tabular}{|l|l|l|}
\hline & $\begin{array}{l}\text { agreement the employer has to obtain } \\
\text { the permission of a state body or third } \\
\text { body prior to an individual dismissal. }\end{array}$ & $\begin{array}{l}\text { dismissal jurisdiction in 1971 (see now Employment } \\
\text { Equals } 0.67 \text { if a state body or third } \\
\text { written reasons in writing. } \\
\text { party has to be notified prior to the } \\
\text { dismissal. }\end{array}$ \\
$\begin{array}{l}\text { Equals } 0.33 \text { if the employer has to give } \\
\text { the worker written reasons for the } \\
\text { dismissal. }\end{array}$ \\
$\begin{array}{l}\text { Equals } 0 \text { if an oral statement of } \\
\text { dismissal to the worker suffices. }\end{array}$ \\
$\begin{array}{l}\text { Scope for further gradations between } 0 \\
\text { and } 1 \text { to reflect changes in the strength } \\
\text { of the law. }\end{array}$ \\
\hline
\end{tabular}




\begin{tabular}{|c|c|c|c|}
\hline 23. Redundancy selection & $\begin{array}{l}\text { Equals } 1 \text { if by law or binding collective } \\
\text { agreement the employer must follow } \\
\text { priority rules based on seniority, } \\
\text { marital status, number or dependants, } \\
\text { etc., prior to dismissing for } \\
\text { redundancy. } \\
\text { Equals } 0 \text { otherwise. } \\
\text { Scope for further gradations between } 0 \\
\text { and } 1 \text { to reflect changes in the strength } \\
\text { of the law. }\end{array}$ & $\begin{array}{l}\text { 1970-1973: } 0 \\
\text { 1974-: } 1\end{array}$ & $\begin{array}{l}\text { Dismissal in breach of a 'customary' selection procedure } \\
\text { such as 'last in, first out' was automatically unfair } \\
\text { between } 1975 \text { (Trade Union and Labour Relations Act } \\
\text { 1974) and } 1989 \text { (Employment Act 1989). After 1989, the } \\
\text { employer continued to be under a duty, under general } \\
\text { unfair dismissal law, to have regard to priority rules } \\
\text { governing selection for redundancy. }\end{array}$ \\
\hline 24. Priority in re-employment & $\begin{array}{l}\text { Equals } 1 \text { if by law or binding collective } \\
\text { agreement the employer must follow } \\
\text { priority rules relating to the re- } \\
\text { employment of former workers. } \\
\text { Equals } 0 \text { otherwise. }\end{array}$ & 1970-: 0 & $\begin{array}{l}\text { There is no rule of priority re-employment in UK labour } \\
\text { law. }\end{array}$ \\
\hline
\end{tabular}




\begin{tabular}{|l|l|l|l|}
\hline & $\begin{array}{l}\text { Scope for further gradations between } 0 \\
\text { and } 1 \text { to reflect changes in the strength } \\
\text { of the law. }\end{array}$ & $\begin{array}{l}\text { Measures the regulation of dismssal, } \\
\text { calculated as the average of variables } \\
\mathbf{1 6 - 2 4}\end{array}$ \\
\hline C. Regulation of dismissal &
\end{tabular}

Source: CBR Labour Regulation Dataset (Deakin, Lele and Siems, 2007; http://www.cbr.cam.ac.uk/research/programme2/project2-20.htm). 